\title{
Phytoremediation of Gold Mine Tailings Amended with Iron-Coated and Uncoated Rice Husk Ash by Vetiver Grass (Vetiveria zizanioides (Linn.) Nash)
}

\author{
F. S. Tariq, ${ }^{1}$ A. W. Samsuri, ${ }^{1}$ D. S. Karam, ${ }^{1}$ and A. Z. Aris ${ }^{2}$ \\ ${ }^{1}$ Department of Land Management, Faculty of Agriculture, Universiti Putra Malaysia (UPM), \\ 43400 Serdang, Selangor Darul Ehsan, Malaysia \\ ${ }^{2}$ Environmental Forensics Research Centre, Faculty of Environmental Studies, Universiti Putra Malaysia (UPM), \\ 43400 Serdang, Selangor Darul Ehsan, Malaysia \\ Correspondence should be addressed to A. W. Samsuri; samsuriaw@upm.edu.my
}

Received 24 November 2015; Accepted 11 April 2016

Academic Editor: Ezio Ranieri

Copyright (C) 2016 F. S. Tariq et al. This is an open access article distributed under the Creative Commons Attribution License, which permits unrestricted use, distribution, and reproduction in any medium, provided the original work is properly cited.

This study was undertaken to determine the effects of rice husk ash (RHA) and iron-coated rice husk ash (Fe-RHA) on phytoavailability of $\mathrm{As}, \mathrm{Cd}, \mathrm{Cr}, \mathrm{Cu}, \mathrm{Mn}, \mathrm{Pb}$, and $\mathrm{Zn}$ to vetiver grass grown in gold mine tailings amended with either RHA or Fe-RHA at $0 \%, 5 \%, 10 \%$, and $20 \%(\mathrm{w} / \mathrm{w})$. The results showed that the RHA amended tailings recorded higher concentration of As in the shoot and the root and higher concentration of $\mathrm{Cr}$ and $\mathrm{Mn}$ in the root compared to the untreated tailings which was used as a control. The biological accumulation coefficient (BAC) and bioconcentration factor (BCF) values of the vetiver grass for As and $\mathrm{Zn}$ increased with RHA application rate but the biological transfer coefficient (BTC) values of As and Zn were decreased. In Fe-RHA amended samples, As concentration in the shoot and root concentrations of $\mathrm{Cd}$ and $\mathrm{Zn}$ were significantly higher compared to the control. The Fe-RHA treated samples had lower BAC and BTC values for As and $\mathrm{Zn}$ than the control. However, the BCF values for those elements were higher than the control. The concentration of $\mathrm{Pb}$ was not detected in any of the samples.

\section{Introduction}

Tailings are the components of the primary mineral-bearing rock left after the extraction of minerals like gold, copper, and silver [1]. Mine tailings are regarded as a major source of environmental pollution due to the presence of high concentration of trace elements in the tailings, which may cause various health effects. The heavy metals in mine tailings are quickly discharged and distributed into the ground water causing serious environmental and health issues in the vicinity of the mine area [2]. Hence, gold mine tailings require proper management to reduce the release of heavy metals into the environment.

There are several methods of cleaning up the harmful effects of heavy metal on contaminated sites which include, among others, physical removal (excavation), in situ stabilization of these metals, and utilization of plants to extract the metals from the polluted site. Each of these approaches nevertheless has its advantages and disadvantages and its success depends on the nature and size of the contaminated site. However, using green plants to contain, degrade, or eliminate metals, for the purpose of removing them is efficient and cost-effective and involves nonenvironmental disruptive compared to operations that require excavation of soil. Different plants have different phytoextraction potentials depending upon the environments and their genetic variability. The ability of plants to take up heavy metals and transfer them from the shoots to the roots is very important in phytoremediation [3]. Phytoremediation can be considerably advantageous when the metals are in the soil solution rather than held by soil constituents and this can be achieved by using different techniques such as adding soil acidifiers, organic and inorganic compounds, and chelates [4]. Organic amendments can be used to either mobilize or immobilize toxic metals in contaminated soils $[5,6]$. In the mobilization technique, the metal(loid)s are released into the soil and are 
subsequently removed through the native plant species. Plant growth on metal-contaminated soil may be enhanced as a result of organic amendments [7]. Chemical portioning and distribution are also affected by organic amendments [8], which may influence the phytoavailability of metals. A field study was conducted by Singh and Agrawal [9] to assess the suitability of sewage sludge amendment in soil for rice (Oryza sativa $L$.) by evaluating the heavy metal accumulation and growth of plants in soil amended with sewage sludge at either $0,3,4.5,6,9$, or $12 \mathrm{~kg} \mathrm{~m}^{-2}$. They found that sewage sludge amendment modified the physicochemical properties of soil, thus increasing the availability of heavy metals in soil and consequently resulting in higher accumulation in plant parts.

The use of waste-based materials for environmental conservation has been stressed under Malaysia’s Green Strategies of the National Policy on the Environment [10]. Solid waste disposal is becoming a major issue in Malaysia; for example, milling processes generate approximately $300000 \mathrm{mt}$ (metric ton) of rice husk annually. Consequently, burning is estimated to produce more than $63000 \mathrm{mt}$ of ash a year [11]. Rice husk is regarded as agricultural waste, comprising around $20 \%$ of the paddy weight, and its annual gross production is 545 million metric tons worldwide [12]. Rice husk ash is a by-product produced from the burning of rice husk. The rice husk and its ash may be used as a natural, low cost adsorbent to remove toxic metals. The ash also contains compounds such as silica, cellulose, lignin, and hemicellulose with binding sites capable of taking up metals $[13,14]$. Also, the ash derived from rice husk has good adsorptive ability and it has been used previously by researchers to remove metal ions [15], dye [16], and filtration of arsenic from water [17]. In addition, Nakbanpote et al. [18] tested the ability of RHA to adsorb gold-thiourea complex and the results have shown that the RHA absorb more gold than conventionally activated carbon. There are a number of studies that proved that RHA has a good ability to remove heavy metals such as $\mathrm{Cd}, \mathrm{Pb}, \mathrm{Zn}, \mathrm{Cu}, \mathrm{Mn}$, and $\mathrm{Hg}$ from aquatic solution $[12,16,19]$. However, there is no information available in the literature for the simultaneous phytoremediation of heavy metals by RHA. Thus, the main objectives of the present study were to determine the effects of rice husk ash (RHA) and Fe-coated RHA on the ability of vetiver grass to phytoremediate mine tailings contaminated with $\mathrm{As}, \mathrm{Cd}, \mathrm{Cr}, \mathrm{Cu}, \mathrm{Mn}, \mathrm{Pb}$, and $\mathrm{Zn}$.

\section{Materials and Methods}

2.1. Chemicals and Reagents. All the chemical reagents were of analytical grade, and the solutions were prepared using a Milli-Q system (Direct-Q ${ }^{\circledR} 3 \mathrm{UV}$ ) ultrapure water (electrical resistivity $18.2 \mathrm{M} \Omega \mathrm{cm}^{-1}$ ). Analytical grade sodium arsenate, cadmium nitrate tetrahydrate, chromium(III) nitrate nonahydrate, copper(II) chloride, manganese(II) sulfate monohydrate, lead(II) nitrate, zinc chloride, and iron(III) chloride were purchased from Sigma-Aldrich.

2.2. Tailings Preparation and Analyses. The tailings were collected from a gold mine located in the state of Pahang, Peninsular Malaysia. Composite samples were taken using a stainless steel scoop from the upper $30 \mathrm{~cm}$ of the tailings. The samples were taken from this layer because they were fresh samples and not waterlogged. The samples were brought to the laboratory and immediately air-dried, homogenized, and grounded to pass through a $2 \mathrm{~mm}$ sieve. The samples were stored in plastic bags prior to analysis. The particle size distribution of the tailing was measured using a pipette method [20]. Samples of tailings/water ratio of $1: 2.5$ were equilibrated for 24 hours and then the $\mathrm{pH}$ and $\mathrm{EC}$ were measured by using Metrohm $827 \mathrm{pH}$ meter and Eutech Instruments CON $700 \mathrm{EC}$ meter, respectively. Exchangeable bases and CEC were determined using $1 \mathrm{M} \mathrm{NH}_{4} \mathrm{OAc}$ buffered at $\mathrm{pH} 7$ [21]. The extracted $\mathrm{NH}_{4}{ }^{+}$was measured using Lachat QuikChem 8000 Series FIA+ autoanalyzer. The carbons, nitrogen, and sulfur, components of tailings sample, were determined by using a CNS elemental analyzer (model: LECO TruMac CNS Analyzer). One gram of tailing sample was digested with a mixture of three concentrated acids $\left(4 \mathrm{~mL} \mathrm{HCl}, 2 \mathrm{~mL} \mathrm{HNO}_{3}\right.$, and $2 \mathrm{mLHF}$ and filtered through Whatman 44 ashless diameter $125 \mathrm{~mm}$ filter papers for total $\mathrm{P}, \mathrm{Ca}, \mathrm{Mg}, \mathrm{K}$, and $\mathrm{Na}$ determination) [22]. The concentrations of $\mathrm{P}, \mathrm{Ca}, \mathrm{Mg}, \mathrm{K}$, and $\mathrm{Na}$ elements in the digests were determined with Perkin Elmer AAnalyst 400 atomic absorption spectrophotometers and $\mathrm{P}$ was measured using an autoanalyzer (Lachat Instruments QuikChem 8000 Series FIA+ System). The acid neutralizing capacity (ANC) was determined using the method described by Shu et al. [23], while the amount of $\mathrm{CaCO}_{3}$ was determined by acid neutralization method [24]. The total amount of heavy metals in the tailings was determined using a method modified from Güven and Akinci [25]. Details of the digestion programs are presented in Table 1. The digests were then filtered through a $0.45 \mu \mathrm{m}$ membrane filter, diluted to $50 \mathrm{~mL}$, and stored prior to analysis. The metal concentrations were analyzed by Perkin Elmer Optima 8300 Inductively Coupled Plasma Optical Emission Spectrometry (ICP-OES).

2.3. Rice Husk Ash Characterization. Rice husk ash (RHA) was obtained from a factory located at Sungai Besar, in the state of Selangor, Peninsular Malaysia. The ash was passed through $1 \mathrm{~mm}$ sieve and analyzed for its chemical and physical properties. The $\mathrm{pH}$ was measured in a $0.5: 100(\mathrm{w} / \mathrm{v})$ $\mathrm{RHA}: \mathrm{H}_{2} \mathrm{O}$ suspension and the electrical conductivity (EC) was measured by shaking $1 \mathrm{~g}$ sample in $20 \mathrm{~mL}$ water for two hours [26]. The $\mathrm{pH}$ and EC were measured using the instruments described previously. The ash content was determined by using a dry combustion method [27]. The cation exchange capacity (CEC) was measured using the method described by Song and Guo [28].

The surface area of the RHA was measured by $\mathrm{N}_{2}$ adsorption at $77.3 \mathrm{~K}$, using a Quantachrome version 2.01 (Quantachrome AS1Win ${ }^{\mathrm{TM}}$ ) surface area analyzer. The RHA sample was degassed at $100^{\circ} \mathrm{C}$ for $9 \mathrm{~h}$ prior to $\mathrm{N}_{2}$ adsorption. The multipoint Brunauer-Emmett-Teller (BET) method was employed to calculate the total surface area. The Scanning Electron Microscope-Electron Dispersive Spectroscopy (SEM-EDS) was used to study the RHA morphology, and Fourier Transformed Infrared Spectroscopy (Perkin Elmer 
TABLE 1: The operating conditions for the microwave digestion system.

\begin{tabular}{|c|c|c|c|c|c|}
\hline Samples & Reagents (mL) & Steps program & Power (watt) & Time (min) & Temperature $\left({ }^{\circ} \mathrm{C}\right)$ \\
\hline \multicolumn{6}{|l|}{ Tailings } \\
\hline $0.5 \mathrm{~g}$ & $\begin{array}{c}65 \% \mathrm{HNO}_{3}(6 \mathrm{~mL}) \\
37 \% \mathrm{HCl}(2 \mathrm{~mL}) \\
40 \% \mathrm{HF}(2 \mathrm{~mL})\end{array}$ & $\begin{array}{l}1 \\
2 \\
3 \\
4\end{array}$ & $\begin{array}{c}200 \\
400 \\
600 \\
0\end{array}$ & $\begin{array}{c}8 \\
7 \\
1 \\
10\end{array}$ & $\begin{array}{l}150 \\
180 \\
200 \\
200\end{array}$ \\
\hline \multicolumn{6}{|c|}{ Vetiver grass } \\
\hline $0.25 \mathrm{~g}$ & $\begin{array}{l}65 \% \mathrm{HNO}_{3}(6 \mathrm{~mL}) \\
30 \% \mathrm{H}_{2} \mathrm{O}_{2}(2 \mathrm{~mL})\end{array}$ & $\begin{array}{l}1 \\
2 \\
3 \\
4\end{array}$ & $\begin{array}{c}250 \\
500 \\
750 \\
0\end{array}$ & $\begin{array}{c}5 \\
10 \\
5 \\
15\end{array}$ & $\begin{array}{l}100 \\
150 \\
200 \\
200\end{array}$ \\
\hline
\end{tabular}

FTIR-2000 spectrometer) was used to determine the RHA surface functional groups.

2.4. Preparation of Iron-Coated Rice Husk Ash (Fe-RHA). Surface modification of the RHA was done by coating it with Fe(III) as described by Samsuri et al. [29]. The RHA was weighed and washed several times with deionized water and then dried for $48 \mathrm{~h}$ in an oven at $50^{\circ} \mathrm{C}$. Then, the sample was soaked in a solution containing $2000 \mathrm{mg} \mathrm{L}^{-1}$ of $\mathrm{Fe}(\mathrm{III})$ prepared using $\mathrm{FeCl}_{3}$ salt. The solution $\mathrm{pH}$ was adjusted to 6 using either $0.1 \mathrm{M} \mathrm{HCl}$ or $0.1 \mathrm{M} \mathrm{NaOH}$. The mixture of RHA and $\mathrm{Fe}$ (III) solution was stirred several times per day for four days manually and then filtered on Whatman no. 42 filter paper and the rice husk was washed with deionized water several times to remove the free $\mathrm{Fe}$ until no more $\mathrm{Fe}$ was detected in the filtrate.

2.5. Greenhouse Study. Untreated tailings (control) and tailings treated with three rates $(5,10$, or $20 \% \mathrm{w} / \mathrm{w})$ of either RHA or Fe-RHA were used for this experiment. Amended tailings were thoroughly homogenized in large plastic containers, and water was added to field capacity and then transferred to plastic bags and kept in a climate-controlled dark room for four weeks. From each bag, approximately $20 \mathrm{~g}$ sample was taken to determine the $\mathrm{pH}$ and $\mathrm{EC}$ at the end of incubation. Pot experiments were conducted in a glass house using square plastic tube pots measuring $5.4 \times 5.4 \mathrm{~cm}$ at the top and $1.5 \times$ $1.5 \mathrm{~cm}$ at the bottom and $29 \mathrm{~cm}$ in height with $50 \mathrm{~g}$ of acid washed sand placed at the base of the pots. Then, $500 \mathrm{~g}$ of tailing mixture was poured into each pot and a one-month age vetiver grass seedling was transplanted into the pot. The experimental units were arranged using a randomized complete block design. The seedlings were watered daily and were allowed to grow for 75 days. At the end of the experiment, the plants were harvested, and the shoots and roots were separated. The plant parts were washed with deionized water several times to remove the tailings and then dried at $60^{\circ} \mathrm{C}$ for $72 \mathrm{~h}$ and weighed for dry biomass determination. The heavy metals ( $\mathrm{As}, \mathrm{Cd}, \mathrm{Cr}, \mathrm{Cu}, \mathrm{Mn}, \mathrm{Pb}$, and $\mathrm{Zn}$ ) contents in the plant parts were analyzed by ICP-OES after grinding and approximately $0.25 \mathrm{~g}$ of sample digested with $6 \mathrm{~mL}$ of $\mathrm{HNO}_{3}$ $65 \%$ and $2 \mathrm{~mL}$ of $\mathrm{H}_{2} \mathrm{O}_{2} 30 \%$ in microwave digestion system; according to the digestion program presented in Table 1 , the resulting solutions were cooled and diluted to $50 \mathrm{~mL}$ with ultrapure water. The biological accumulation coefficient (BAC) is defined as the concentration of metals in plant shoots divided by the metal concentration in soil [30] and is given in

$$
\mathrm{BAC}=\frac{[\text { Metal }] \text { shoot }}{[\text { Metal }] \text { soil }} .
$$

The biological transfer coefficient (BTC) is defined as the ratio of metal concentration in shoot to the root of the plant [30] and is given in

$$
\text { BTC }=\frac{[\text { Metal }] \text { shoot }}{[\text { Metal }] \text { root }}
$$

The bioconcentration factor (BCF) was calculated as the ratio of the concentration of metal in plant root to the soil [31] as given in

$$
\mathrm{BCF}=\frac{[\text { Metal }] \text { root }}{[\text { Metal }] \text { soil }} .
$$

2.6. Statistical Analysis. All data were checked for normality and homogeneity of variances prior to statistical analysis. The precision of the data was calculated and expressed as a standard deviation (SD). Later the data were subjected to statistical analysis of variance (ANOVA) using MINITAB version 16 at the 5\% significance level and Tukey's test was employed for mean separation.

\section{Results and Discussion}

3.1. Physicochemical Properties of the Gold Mine Tailings and RHA and Fe-RHA. The selected physicochemical properties of the gold mine tailings are shown in Table 2. The tailings texture was silty loam (14.23\% clay; $36.02 \%$ sand; $49.68 \%$ silt) and the $\mathrm{pH}$ was slightly alkaline at 7.90 due to the use of lime to treat the waste water which was pumped back to the retaining pond. The tailings had high acid neutralization capacity and calcium carbonate content which were $63.9 \mathrm{H}_{2} \mathrm{SO}_{4} \mathrm{t}^{-1}$ and $56 \mathrm{~g} \mathrm{~kg}^{-1}$, respectively. The high concentrations of total heavy metals As $\left(1625.251 \mathrm{mg} \mathrm{kg}^{-1}\right)$, $\mathrm{Cd}\left(57 \mathrm{mg} \mathrm{kg}^{-1}\right), \mathrm{Cr}\left(31.44 \mathrm{mg} \mathrm{kg}^{-1}\right), \mathrm{Cu}\left(75.6 \mathrm{mg} \mathrm{kg}^{-1}\right), \mathrm{Mn}$ (790.03 $\left.\mathrm{mg} \mathrm{kg}^{-1}\right), \mathrm{Pb}\left(81.8 \mathrm{mg} \mathrm{kg}^{-1}\right)$, and $\mathrm{Zn}\left(174.8 \mathrm{mg} \mathrm{kg}^{-1}\right)$ 
TABLE 2: The selected physicochemical properties of the gold mine tailings.

\begin{tabular}{lc}
\hline Parameters & Value \\
\hline Clay $(\%)$ & $14.23 \pm 0.61$ \\
Silt $\%)$ & $49.68 \pm 0.89$ \\
Sand $(\%)$ & $36.02 \pm 1.43$ \\
Texture (USDA) & Silty loam \\
Moisture content \% at 33 kpa & $25.90 \pm 0.36$ \\
Moisture content \% at $1500 \mathrm{kpa}$ & $4.04 \pm 0.81$ \\
pH & $7.90 \pm 0.02$ \\
EC $\left(\mathrm{dS} \mathrm{m}{ }^{-1}\right)$ & $1.48 \pm 0.01$ \\
CEC $\left(\mathrm{cmol}_{(+)} \mathrm{kg}^{-1}\right)$ & $10.75 \pm 0.83$ \\
Total carbon $(\%)$ & $1.56 \pm 0.01$ \\
ANC $\left(\mathrm{kg} \mathrm{H}_{2} \mathrm{SO}_{4} \mathrm{t}^{-1}\right)$ & $63.90 \pm 2.01$ \\
Total N $(\%)$ & $0.036 \pm 0.004$ \\
Total P $(\%)$ & $0.076 \pm 0.002$ \\
Total K $(\%)$ & $0.196 \pm 0.005$ \\
Total S $(\%)$ & $0.140 \pm 011$ \\
Total Ca $\left(\mathrm{mg} \mathrm{kg}^{-1}\right)$ & $8600 \pm 30.51$ \\
Total Mg $\left(\mathrm{mg} \mathrm{kg}^{-1}\right)$ & $10750 \pm 152$ \\
Total Na $\left(\mathrm{mg} \mathrm{kg}^{-1}\right)$ & $1480 \pm 21$ \\
Total As $\left(\mathrm{mg} \mathrm{kg}^{-1}\right)$ & $1625.25 \pm 12$ \\
Total Cd $\left(\mathrm{mg} \mathrm{kg}^{-1}\right)$ & $57.00 \pm 1.41$ \\
Total Cr $\left(\mathrm{mg} \mathrm{kg}^{-1}\right)$ & $31.44 \pm 0.61$ \\
Total Cu $\left(\mathrm{mg} \mathrm{kg}^{-1}\right)$ & $75.60 \pm 0.65$ \\
Total $\mathrm{Mn}\left(\mathrm{mg} \mathrm{kg}^{-1}\right)$ & $790.03 \pm 9.98$ \\
Total Pb $\left(\mathrm{mg} \mathrm{kg}^{-1}\right)$ & $174.80 \pm 1.18$ \\
Total $\mathrm{Zn}\left(\mathrm{mg} \mathrm{kg}^{-1}\right)$ & $16420 \pm 402$ \\
Total Fe $\left(\mathrm{mg} \mathrm{kg}^{-1}\right)$ & \\
\hline
\end{tabular}

Mean of three replicates \pm SD.

indicated that the tailings were highly contaminated with these elements. On the other hand the tailings had low CEC $\left(10.75 \mathrm{cmol}_{(+)} \mathrm{kg}^{-1}\right), \mathrm{N}(0.036 \%), \mathrm{P}(0.076 \%)$, and $\mathrm{K}(0.196 \%)$ contents. In addition to that, the selected physicochemical properties of the RHA and Fe-RHA are shown in Table 3. The $\mathrm{pH}, \mathrm{EC}, \mathrm{CEC}$, total C, DOC, total $\mathrm{P}$, total $\mathrm{K}$, total $\mathrm{Ca}^{+2}$, and ash content values of the RHA were higher than the Fe-RHA. On the other hand, total $\mathrm{N}$ and total $\mathrm{Na}$ were higher in the Fe-RHA than RHA. The Fe-RHA also had a larger total surface area, pore surface area, pore volume, and pore radius. However, there was no significant difference in the surface functional groups between RHA and Fe-RHA as indicated by the FTIR spectra (Figure 1). The bands at 615.73 and $619.50 \mathrm{~cm}^{-1}$ are associated with the $\mathrm{C}=\mathrm{C}-\mathrm{H}$ (aromatic) functional group. The bands at 784.61 and $781.83 \mathrm{~cm}^{-1}$ are associated with the $=\mathrm{C}-\mathrm{H}$ out of plane bending and finally the bands at 1057.41 and $1055.05 \mathrm{~cm}^{-1}$ are associated with the $\mathrm{C}-\mathrm{O}$ stretch. The surface morphology, shape, and pores of RHA and Fe-RHA are shown in Figure 2. It can be seen that the meso- and macropores were more abundant than the micropores. Both intact and deformed cellulose and lignin strands are visible in the scanning electron micrograph images (Figure 2).
TABLE 3: The selected physicochemical properties of the RHA and Fe-RHA.

\begin{tabular}{|c|c|c|}
\hline Parameters & RHA & Fe-RHA \\
\hline $\mathrm{pH}$ & $10.33 \pm 0.33$ & $7.24 \pm 0.06$ \\
\hline $\mathrm{EC}\left(\mathrm{dS} \mathrm{m^{-1 } )}\right.$ & $0.56 \pm 0.04$ & $208.33 \pm 0.01$ \\
\hline $\operatorname{CEC~}\left(\mathrm{cmol}_{(+)} \mathrm{kg}^{-1}\right)$ & $13.36 \pm 0.37$ & $11.32 \pm 0.05$ \\
\hline Total C (\%) & $6.44 \pm 0.09$ & $5.45 \pm 0.07$ \\
\hline DOC $\mathrm{mg} \mathrm{kg}^{-1}$ & $818.77 \pm 2.43$ & $800.8 \pm 1.41$ \\
\hline Total N (\%) & $0.047 \pm 0.001$ & $0.11 \pm 0.01$ \\
\hline Total S (\%) & ND & ND \\
\hline Total P (\%) & $0.23 \pm 0.02$ & $0.15 \pm 0.01$ \\
\hline Total K (\%) & $0.098 \pm 0.003$ & $0.03 \pm 0.001$ \\
\hline Ash content (\%) & $8.4 \pm 0.23$ & $6.8 \pm 0.03$ \\
\hline Total $\mathrm{Mg}\left(\mathrm{mg} \mathrm{kg}^{-1}\right)$ & $7800 \pm 17.61$ & $2600 \pm 17.62$ \\
\hline Total $\mathrm{Ca}\left(\mathrm{mg} \mathrm{kg}^{-1}\right)$ & $585 \pm 6.03$ & ND \\
\hline Total $\mathrm{Na}\left(\mathrm{mg} \mathrm{kg}^{-1}\right)$ & $740 \pm 4.58$ & $8100 \pm 25.63$ \\
\hline Total surface area $\left(\mathrm{m}^{2} \mathrm{~g}^{1}\right)$ & 24.252 & 44.686 \\
\hline Pore surface area $\left(\mathrm{m}^{2} \mathrm{~g}^{-1}\right)$ & 4.417 & 5.648 \\
\hline Pore volume $\left(\mathrm{cm}^{3} \mathrm{~g}^{-1}\right)$ & 0.016 & 0.017 \\
\hline Pore radius $(\AA)$ & 17.165 & 19.201 \\
\hline
\end{tabular}

Mean of three replicates \pm SD; ND: not detected.

3.2. Chemical Properties of the Mine Tailings and Dissolved Organic Carbon (DOC) Content after Burning Rice Husk Application. The application of RHA significantly increased the $\mathrm{pH}$ of the tailings in all treatments while Fe-RHA amendment lowered the $\mathrm{pH}$ of the tailings compared with the control (Table 4). The highest $\mathrm{pH}$ value for RHA amended tailings was 9.05 at the highest application rate $(20 \%)$. It is also observed that there was no effect of RHA application on the EC of the mine tailings except at the highest rate (20\%). The results also revealed that both RHA and FeRHA application had no impact on the CEC of the mine tailings. The application of high rates of RHA and Fe-RHA significantly increased DOC of the mine tailings. The DOC of the tailings amended with $10 \%$ and 20\% RHA and 20\% Fe-RHA were higher compared with the control (Table 4). The highest DOC value for RHA amended tailings was $919.80 \mathrm{mg} \mathrm{kg}^{-1}$ at the $20 \%(\mathrm{w} / \mathrm{w})$ application rate.

The increases in the $\mathrm{pH}, \mathrm{EC}$, and DOC of the tailings with RHA application were possibly due to the high ash content, DOC, elemental concentrations, and the presence and dissolution of hydroxides and carbonates in the RHA (Table 3). Even though the CEC of the RHA was higher than the CEC of the tailings, the addition of RHA did not increase the CEC of the tailings significantly. This might be attributed to the short time span between samples incubation and the time of CEC measurement. Karmakar et al. [32] and Masulili et al. [33] found that the application of RHA to soil increased soil $\mathrm{pH}$, organic carbon, and nutrient availability. Therefore, it can be concluded that the effects of RHA application on the $\mathrm{pH}, \mathrm{EC}$, and $\mathrm{DOC}$ of the tailings depend on both the properties of the RHA and the tailings.

3.3. Concentrations of Heavy Metals in Shoot, Root, and Total Heavy Metal Uptake of the Vetiver Grass. Figures 3(a) and 
TABLE 4: The $\mathrm{pH}\left(1: 2.5 \mathrm{w}_{\text {soil }} / \mathrm{v}_{\text {water }}\right)$, EC $\left(\mu \mathrm{S} \mathrm{cm}^{-1}\right)$, and CEC $\left(\mathrm{cmol}_{(+)} \mathrm{kg}^{-1}\right)$ of the mine tailings amended with the ashes (mean $n=3$, $\left.\pm \mathrm{SD}\right)$. Different letters correspond to significant differences between rates of the same ash $(P<0.05)$ in the same column.

\begin{tabular}{|c|c|c|c|c|c|c|c|c|c|}
\hline Type & Rates (\%) & $\mathrm{pH}$ & SD & $\mathrm{EC}\left(\mathrm{dS} \mathrm{m^{-1 } )}\right.$ & SD & $\mathrm{CEC}\left(\mathrm{cmol}+\mathrm{kg}^{-1}\right)$ & SD & DOC $(\mathrm{mg} / \mathrm{kg})$ & SD \\
\hline Control & 0 & $7.90^{\mathrm{d}}$ & 0.02 & $1.48^{\mathrm{b}}$ & 0.012 & $11.75^{\mathrm{a}}$ & 0.83 & $823.03^{b}$ & 5.28 \\
\hline RHA & 5 & $8.45^{\mathrm{c}}$ & 0.01 & $1.48^{\mathrm{b}}$ & 0.015 & $10.05^{\mathrm{a}}$ & 1.47 & $844.86^{\mathrm{b}}$ & 7.84 \\
\hline RHA & 10 & $8.55^{\mathrm{b}}$ & 0.00 & $1.49^{\mathrm{b}}$ & 0.015 & $11.75^{\mathrm{a}}$ & 0.63 & $904.43^{\mathrm{a}}$ & 6.59 \\
\hline RHA & 20 & $9.05^{\mathrm{a}}$ & 0.02 & $1.58^{\mathrm{a}}$ & 0.045 & $12.46^{\mathrm{a}}$ & 1.46 & $919.80^{\mathrm{a}}$ & 10.30 \\
\hline Control & 0 & $7.90^{\mathrm{a}}$ & 0.02 & $1.48^{\mathrm{b}}$ & 0.012 & $11.75^{\mathrm{a}}$ & 0.83 & $823.03^{\mathrm{a}}$ & 5.28 \\
\hline Fe-RHA & 5 & $7.73^{\mathrm{b}}$ & 0.03 & $1.48^{\mathrm{b}}$ & 0.034 & $14.12^{\mathrm{a}}$ & 0.12 & $772.43^{\mathrm{b}}$ & 12.41 \\
\hline Fe-RHA & 10 & $7.70^{\mathrm{b}}$ & 0.04 & $1.51^{\mathrm{b}}$ & 0.012 & $12.48^{\mathrm{a}}$ & 2.56 & $815.17^{\mathrm{a}}$ & 8.57 \\
\hline Fe-RHA & 20 & $7.66^{\mathrm{b}}$ & 0.06 & $1.64^{\mathrm{a}}$ & 0.008 & $12.25^{\mathrm{a}}$ & 0.23 & $835.63^{\mathrm{a}}$ & 5.54 \\
\hline
\end{tabular}

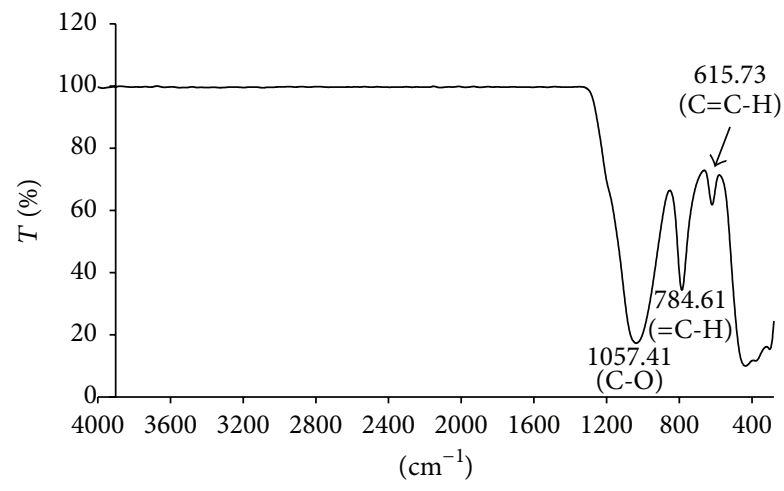

(a)

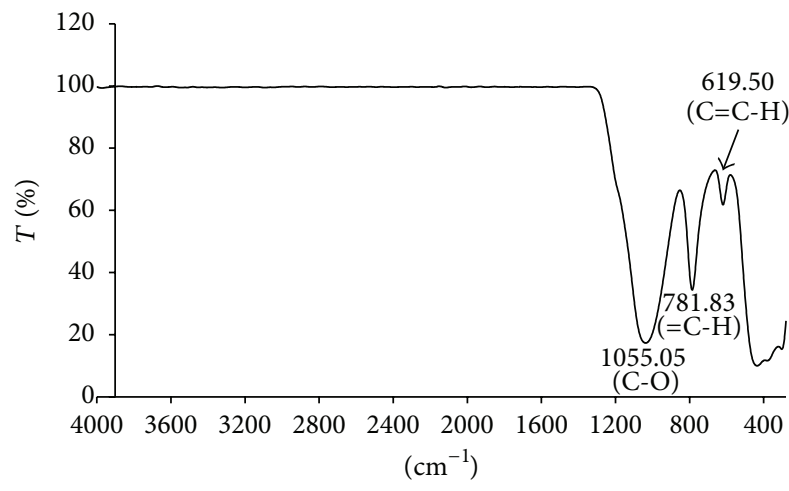

(b)

FIGURE 1: The FTIR spectra of RHA (a) and Fe-RHA (b).

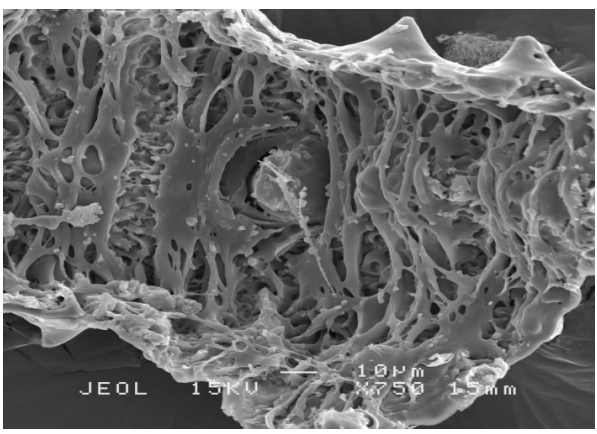

(a)

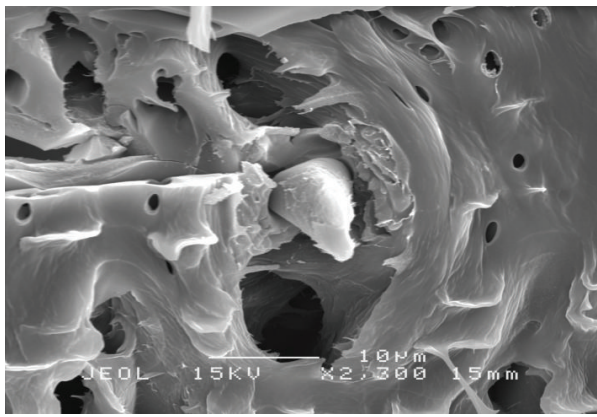

(c)

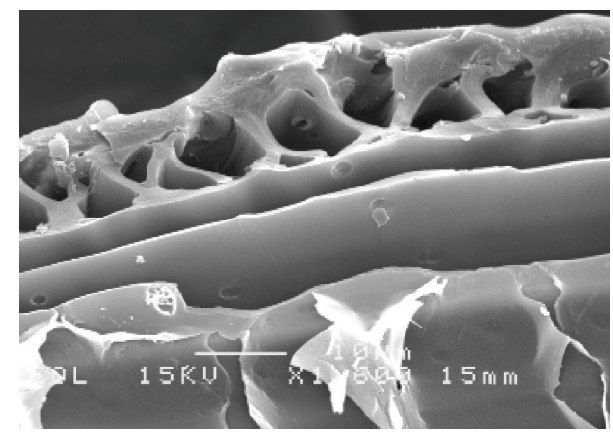

(b)

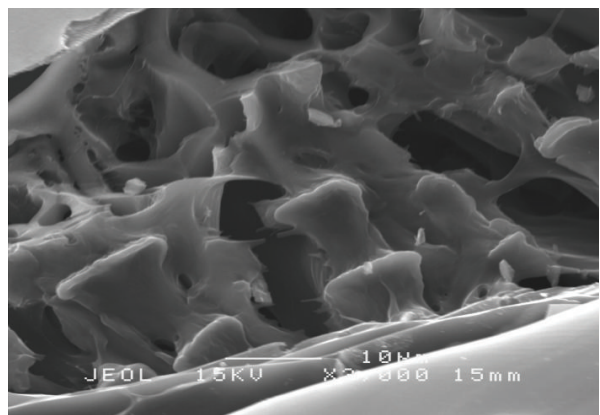

(d)

FIGURE 2: The scanning electron microscope images of the RHA magnified at 750 (a), 1600 (b), 2300 (c), and 3000 times (d). The accelerating voltage of the instrument was maintained at $15 \mathrm{kV}$. 


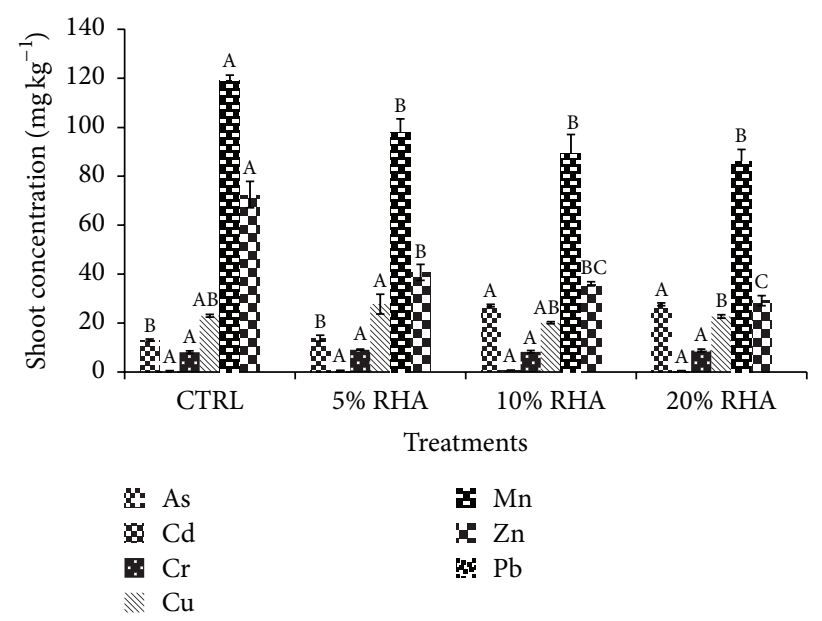

(a)

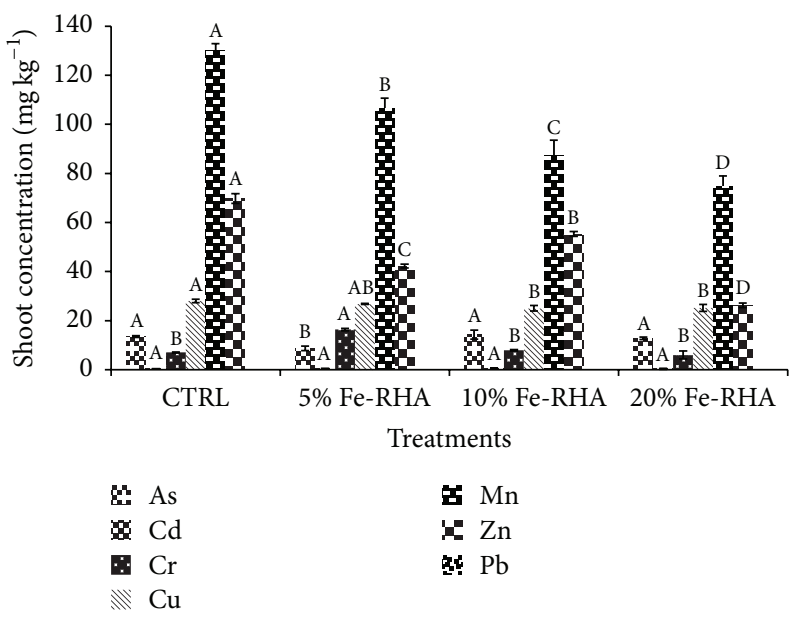

(b)

Figure 3: Concentration ( $\mathrm{mg} \mathrm{kg}^{-1}$ ) of $\mathrm{As}, \mathrm{Cd}, \mathrm{Cr}, \mathrm{Cu}, \mathrm{Mn}, \mathrm{Zn}$, and $\mathrm{Pb}$ in shoot of vetiver grass grown in gold mine amended with (a) RHA and (b) Fe-RHA (mean $n=3, \pm S D)$. Different letters correspond to significant differences between rates of the same ash $(P<0.05)$. Pb was not detected.

3(b) show the concentration of metals in the shoot of the vetiver grass. The As concentration in all RHA amended samples, except at 5\% application rate, was higher than the control (Figure 3(a)). The As concentration in all Fe-RHA treatments, except at 5\% application rate, was not significantly different from the control, while it was significantly decreased in 5\% Fe-RHA application rate (Figure 3(b)). The highest shoot concentration of As $\left(27.733 \mathrm{mg} \mathrm{kg}^{-1}\right)$ was recorded at $20 \%$ RHA. The concentrations of $\mathrm{Mn}$ in the shoot of vetiver grass grown in all RHA treated samples were significantly lower than the control. The lowest shoot concentration of Mn (86.133 $\mathrm{mg} \mathrm{kg}^{-1}$ ) was recorded at 20\% RHA (Figure 3(a)). The shoot concentrations of $\mathrm{Cr}$ and $\mathrm{Cu}$ in all RHA treated samples were not significantly different compared with the control (Figure 3(a)). However, the concentrations of $\mathrm{Cr}, \mathrm{Cu}$, and $\mathrm{Mn}$ in the shoot of vetiver grass grown in all Fe-RHA treated samples were significantly lower than the control except at $5 \%$ application rate for $\mathrm{Cr}$ and $\mathrm{Cu}$ in which the shoot $\mathrm{Cr}$ concentration was higher than control and the shoot concentration of $\mathrm{Cu}$ was not significant compared to the control. The lowest shoot concentrations of $\mathrm{Cr}\left(6.000 \mathrm{mg} \mathrm{kg}^{-1}\right), \mathrm{Cu}$ $\left(25.000 \mathrm{mg} \mathrm{kg}^{-1}\right)$, and $\mathrm{Mn}\left(74.867 \mathrm{mg} \mathrm{kg}^{-1}\right)$ were recorded in tailings amended with $20 \%, 10 \%$, and $20 \%$ Fe-RHA, respectively (Figure 3(b)). The shoot concentrations of $\mathrm{Cd}$ in all RHA and Fe-RHA treated samples were not significantly different compared with the control. However, the shoot concentrations of $\mathrm{Zn}$ in all RHA and Fe-RHA treated samples were lower than the control. The lowest shoot $\mathrm{Zn}$ concentration $\left(26.267 \mathrm{mg} \mathrm{kg}^{-1}\right.$ ) was recorded at $20 \% \mathrm{Fe}-\mathrm{RHA}$.

The two-way analysis of variance (ANOVA) procedure shows the significant $(P<0.05)$ effects of rice husk type and the interaction term of type $*$ rate on the concentration of $\mathrm{As}, \mathrm{Cr}, \mathrm{Cu}$, and $\mathrm{Zn}$ in the shoot systems of the vetiver grass. However, the effects of rice husk type and the interaction term of rate and type were not significant $(P>0.05)$ on $\mathrm{Cd}$ and $\mathrm{Mn}$ shoot concentration of the vetiver grass. However, the application rate of both RHA and Fe-RHA had a significant effect on the concentrations of all elements in the shoot of the vetiver grass.

The concentrations of $\mathrm{As}, \mathrm{Cd}, \mathrm{Cr}, \mathrm{Cu}, \mathrm{Mn}$, and $\mathrm{Zn}$ in the roots of the vetiver grass are shown in Figures 4(a) and 4(b). The root concentrations of As in Fe-RHA and RHA amended samples were higher than the control (Figures 4(a) and $4(\mathrm{~b})$ ). The highest root As concentration (267.400 $\mathrm{mg} \mathrm{kg}^{-1}$ ) was recorded at $20 \%$ RHA treated sample (Figure $4(\mathrm{a})$ ). In contrast, the application of both Fe-RHA and RHA at all rates decreased the concentration of $\mathrm{Cu}$ in the root of vetiver grass compared with the control (Figures 4(a) and 4(b)). The lowest root $\mathrm{Cu}$ concentration $\left(9.133 \mathrm{mg} \mathrm{kg}^{-1}\right)$ was recorded in $5 \%$ RHA treated sample.

In RHA treated samples, the $\mathrm{Cd}$ concentration in the roots decreased with the application rate. However, in $\mathrm{Fe}$ RHA samples only the 5\% Fe-RHA treated sample had a lower $\mathrm{Cd}$ concentration in the root compared with the control. In contrast, the roots $\mathrm{Cr}$ concentration in all RHA treated samples, except at 5\% treated sample, increased compared with the control. The root $\mathrm{Cr}$ concentrations in $\mathrm{Fe}-$ RHA treated samples, except at $20 \%$, were not significantly different from the control. The highest root $\mathrm{Cr}$ concentration $\left(3.733 \mathrm{mg} \mathrm{kg}^{-1}\right)$ was recorded at $20 \%$ RHA treated sample. The application of Fe-RHA at all rates decreased the concentration of $\mathrm{Mn}$ in the root of vetiver grass compared with the control. However, RHA rates had different effects on Mn concentration in root. For instance, root Mn concentration at 5\% RHA treated sample was lower than the control. However, the highest root $\mathrm{Mn}$ concentration $\left(69.067 \mathrm{mg} \mathrm{kg}^{-1}\right.$ ) was recorded in $10 \%$ RHA sample. The application of RHA at all rates increased the concentration of $\mathrm{Zn}$ in the roots of vetiver grass compared with the control. However, in Fe-RHA samples only the 5\% Fe-RHA had a higher $\mathrm{Zn}$ root concentration than the control. The two-way ANOVA analysis for $\mathrm{As}, \mathrm{Cd}, \mathrm{Cr}, \mathrm{Cu}, \mathrm{Mn}$, and $\mathrm{Zn}$ concentration in 


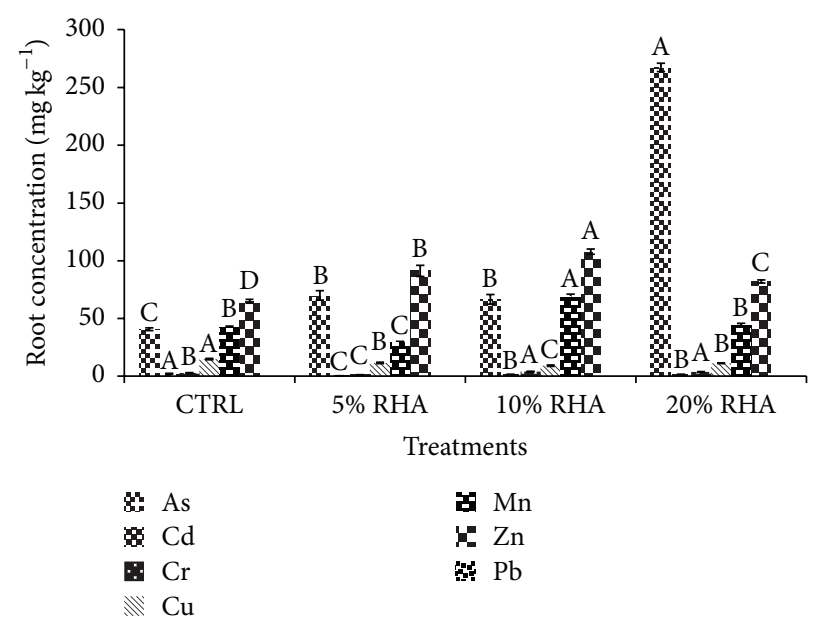

(a)

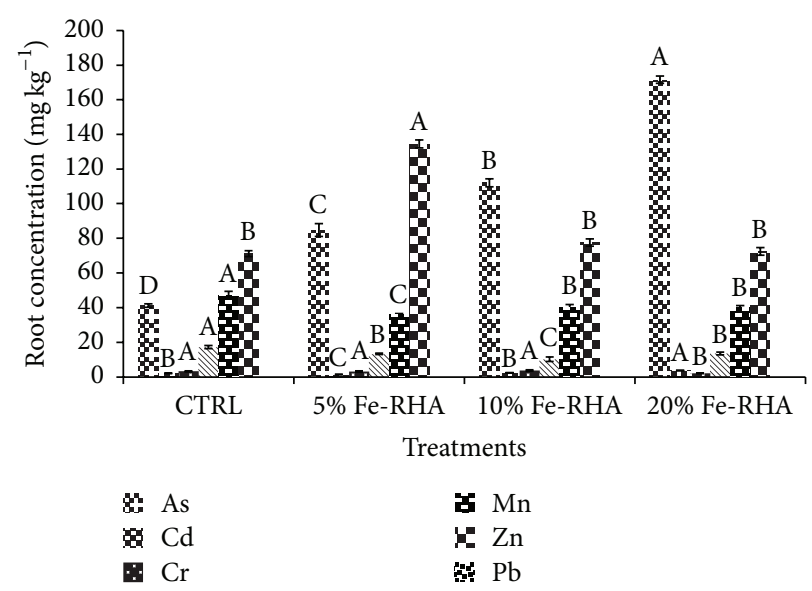

(b)

Figure 4: Concentration $\left(\mathrm{mg} \mathrm{kg}^{-1}\right)$ of $\mathrm{As}, \mathrm{Cd}, \mathrm{Cr}, \mathrm{Cu}, \mathrm{Mn}, \mathrm{Zn}$, and $\mathrm{Pb}$ in root of vetiver grass grown in gold mine amended with Fe- $\mathrm{RHA}$ and RHA (mean $n=3, \pm \mathrm{SD}$ ). Different letters correspond to significant differences between rates of the same ash $(P<0.05)$. Pb was not detected.

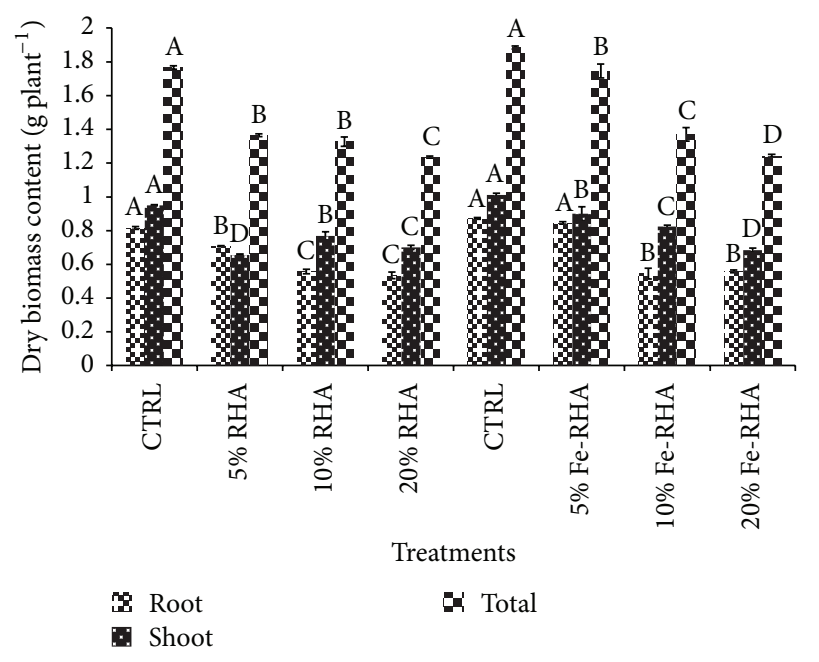

FIGURE 5: Shoot, root, and total dry biomass of vetiver grass grown in gold mine amended with Fe-RHA and RHA (mean $n=3, \pm \mathrm{SD}$ ). Different letters correspond to significant differences between rates of the same ash $(P<0.05)$.

the root system of the vetiver grass is shown. Rice husk ash type had significant $(P<0.05)$ effect on $\mathrm{As}, \mathrm{Cd}, \mathrm{Cu}$, and $\mathrm{Mn}$ concentrations in the roots of the vetiver grass, but not for $\mathrm{Cr}$ and $\mathrm{Zn}$. The two-way ANOVA results also revealed that both rates and the interaction term (type $*$ rates) had a significant effect on the concentrations of all elements in the roots of the vetiver grass, except for $\mathrm{Cu}$.

Figure 5 shows the root, shoot, and total plant dry biomass production of the vetiver grass. Vetiver grass grown in all Fe-RHA and RHA amended tailings had lower root, shoot, and total biomass production compared with the vetiver grass grown in the controls. The lowest dry root, shoot, and total biomass of the vetiver $(0.535,0.657$, and $1.236 \mathrm{~g} \mathrm{plant}^{-1}$ ) were observed in $20 \%, 5 \%$, and $20 \%$
RHA amended samples, respectively (Figure 5). The ANOVA results show that type, rate, and interaction term (type $*$ rate) of Fe-RHA and RHA had a significant effect $(P<0.05)$ on root, shoot, and total plant dry biomass production.

Figures 6(a) and 6(b) show the results of metal uptake in the shoot of vetiver grass grown in mine tailings amended with Fe-RHA and RHA. Amending the tailings with RHA at all rates, except at 5\%, increased the shoot uptake of As in the vetiver grass compared with the controls. The highest As uptake $\left(15.225 \mu \mathrm{g}\right.$ plant $^{-1}$ ) was recorded at $10 \%$ RHA (Figure 6(a)). In contrast, application of Fe-RHA at all rates decreased As uptake in the shoot of vetiver grass (Figure $6(\mathrm{~b})$ ). In addition, the high rate (10\% and $20 \%)$ of RHA and Fe-RHA Application reduced $\mathrm{Cr}, \mathrm{Cu}, \mathrm{Mn}$, and $\mathrm{Zn}$ uptake in the shoot compared with the control. The lowest $\mathrm{Cr}$ (3.346), Cu (11.770), Mn (41.809), and Zn (14.697 $\mu$ g plant $\left.^{-1}\right)$ uptakes were observed in the samples amended with the 20\% Fe-RHA, 10\% RHA, 20\% Fe-RHA, and 20\% Fe-RHA, respectively. However, application of RHA and Fe-RHA at all rates had no significant effect on Cd uptake in the shoot compared with the control. The type of RHA had significant $(P<0.05)$ effect on shoot uptake of As, $\mathrm{Cr}, \mathrm{Cu}, \mathrm{Mn}$, and $\mathrm{Zn}$ by the vetiver grass but not for $\mathrm{Cd}$. However, both application rates and the interaction term (type $*$ rate) had significant $(P<0.05)$ effect on the shoot uptake of all elements by the vetiver grass, except interaction for $\mathrm{Cu}$.

Figures 7(a) and 7(b) also show metal uptake in the roots of vetiver grass grown in mine tailings amended with $\mathrm{Fe}$ RHA and RHA. The root uptakes of As in RHA and Fe-RHA amended samples at all rates were higher than the control. The highest root As uptake $\left(187.504 \mu \mathrm{g} \mathrm{plant}^{-1}\right)$ was recorded in $20 \%$ RHA treated sample (Figure 7(a)) while the lowest root As uptake $\left(38.723 \mu \mathrm{g}\right.$ plant $\left.^{-1}\right)$ was recorded in the control. In contrast, the root uptakes of $\mathrm{Cu}$ in RHA and Fe-RHA amended samples at all rates were lower than the control. The lowest root $\mathrm{Cu}$ uptake $\left(7.031 \mu \mathrm{g}\right.$ plant $\left.^{-1}\right)$ was recorded at $10 \%$ RHA treated sample. The $\mathrm{Cd}$ and $\mathrm{Cr}$ uptake in the 


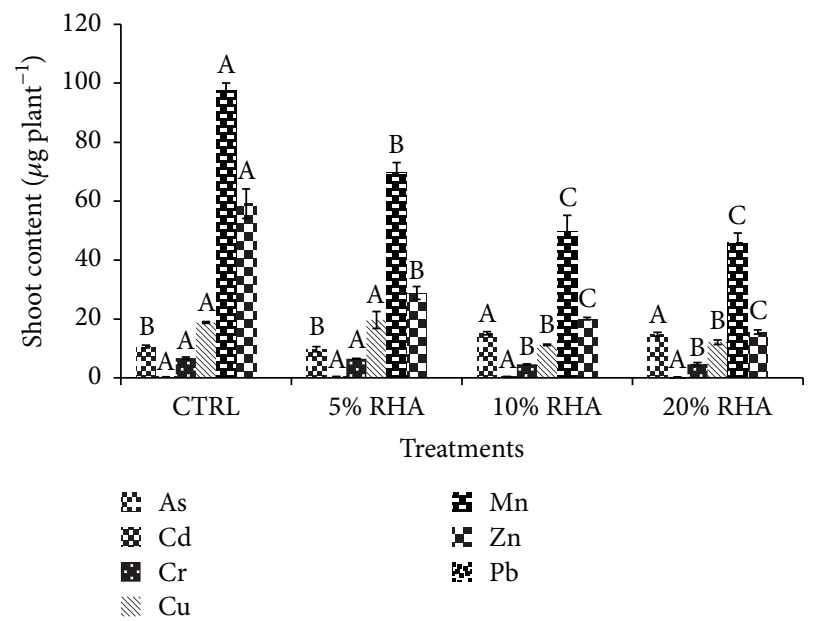

(a)

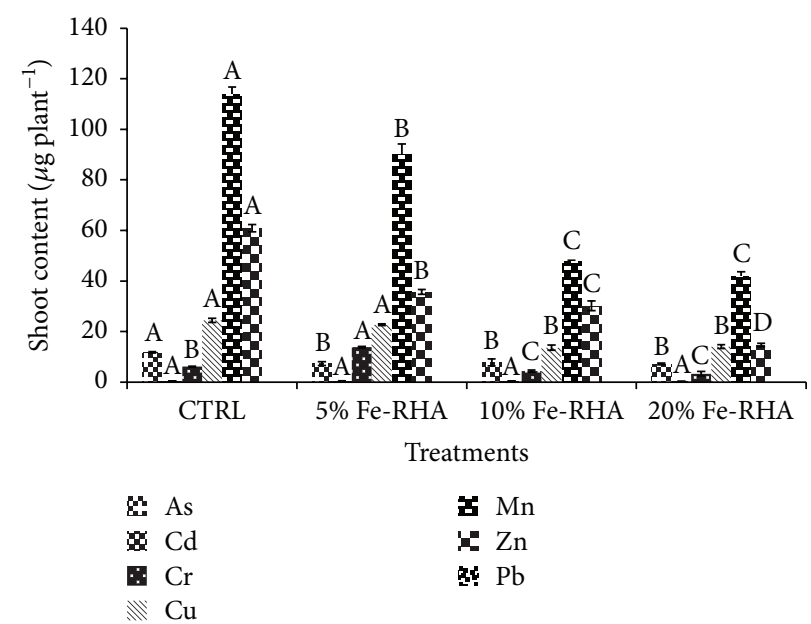

(b)

Figure 6: The uptake of As, $\mathrm{Cd}, \mathrm{Cr}, \mathrm{Cu}, \mathrm{Mn}, \mathrm{Zn}$, and $\mathrm{Pb}\left(\mu \mathrm{g}\right.$ plant $\left.^{-1}\right)$ in shoot of vetiver grass grown in gold mine amended with Fe-RHA and RHA (mean $n=3, \pm \mathrm{SD}$ ). Different letters correspond to significant differences between rates of the same ash $(P<0.05)$. $\mathrm{Pb}$ was not detected.

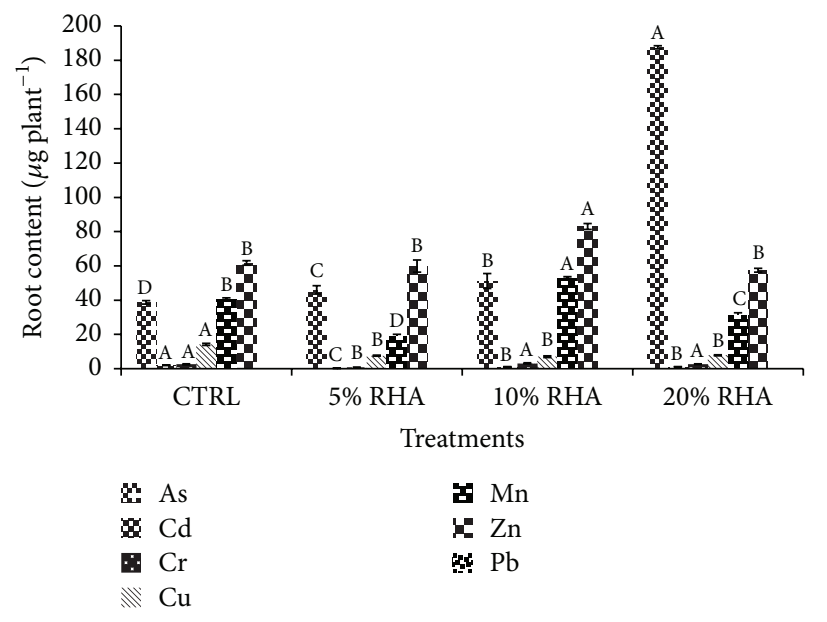

(a)

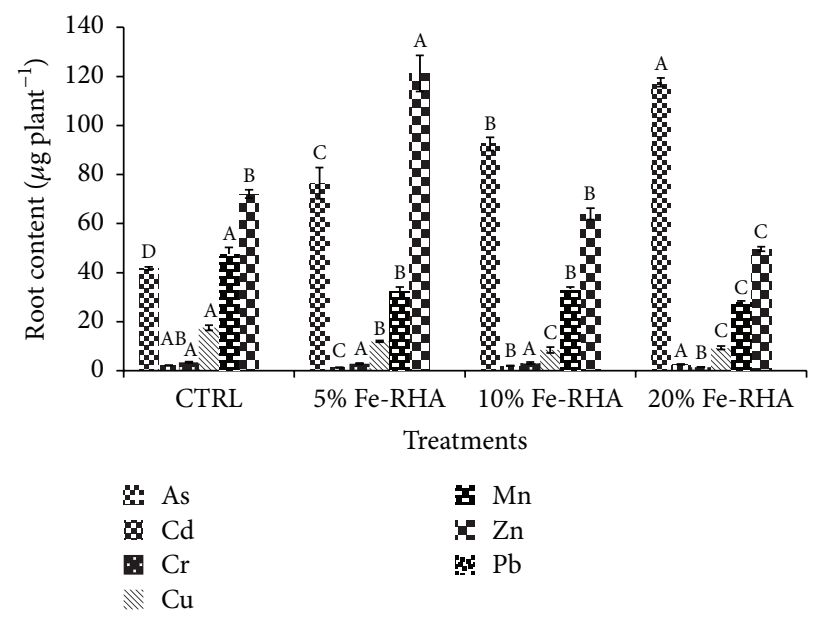

(b)

Figure 7: The uptake of $\mathrm{As}, \mathrm{Cd}, \mathrm{Cr}, \mathrm{Cu}, \mathrm{Mn}, \mathrm{Zn}$, and $\mathrm{Pb}\left(\mu \mathrm{g}_{\text {plant }}{ }^{-1}\right)$ in root of vetiver grass grown in gold mine amended with Fe-RHA and RHA (mean $n=3, \pm \mathrm{SD}$ ). Different letters correspond to significant differences between rates of the same ash $(P<0.05)$. Pb was not detected.

root decreased with increasing RHA rates compared to the control. However, application of Fe-RHA at all rates had no significant effect on $\mathrm{Cd}$ and $\mathrm{Cr}$ uptake in the root, except $5 \% \mathrm{Fe}-\mathrm{RHA}$ for $\mathrm{Cd}$ and $20 \% \mathrm{Fe}-\mathrm{RHA}$ for $\mathrm{Cr}$ when they had a lower uptake in the root compared with the control (Figure 7(b)). Similarly, the application of either Fe-RHA or $\mathrm{RHA}$ at all rates, except the $10 \%$ RHA, decreased the root uptake of Mn of vetiver grass compared with the control. The two-way analysis of variance (ANOVA) procedure shows the significant $(P<0.05)$ effects of rice husk type on the uptake of $\mathrm{Cd}, \mathrm{Cr}, \mathrm{Cu}$, and $\mathrm{Zn}$ in the root systems of the vetiver grass but not for As and Mn. However, both application rates and the interaction term (type $*$ rate) had significant $(P<0.05)$ effect on the root uptake of all elements by the vetiver grass.

The total plant metals uptakes of vetiver grass grown in mine tailings amended with Fe-RHA and RHA are presented in Figures 8(a) and 8(b). The amount of heavy metals uptake by vetiver grass was altered among the treatments. The total As uptake in vetiver grass grown in both Fe-RHA and RHA treated samples at all rates was higher compared with the control. The highest As uptake (202.342 $\left.\mu \mathrm{g} \mathrm{plant}^{-1}\right)$ was recorded in $20 \%$ RHA treated sample (Figure $8(\mathrm{a})$ ). But, the application of RHA and Fe-RHA at all rates decreased the total plant uptake of $\mathrm{Cu}$ and $\mathrm{Mn}$ compared with the control and the lowest $\mathrm{Cu}(18.307)$ and $\mathrm{Mn}\left(69.465 \mu \mathrm{g} \mathrm{plant}^{-1}\right)$ uptakes were recorded at $10 \%$ RHA and $20 \%$ Fe-RHA, respectively. In addition, the application of RHA at all rates reduced the total vetiver grass uptake of $\mathrm{Cd}, \mathrm{Cr}$, and $\mathrm{Zn}$ compared with the control. The lowest Cd (0.643), Cr (7.304), and Zn $\left(73.103 \mu \mathrm{g} \mathrm{plant}^{-1}\right)$ uptakes were recorded by plants grown in $5 \%$, 5\%, and 20\% RHA, respectively. However, in Fe-RHA samples, only plants grown in the $5 \%$ Fe-RHA had lower Cd 


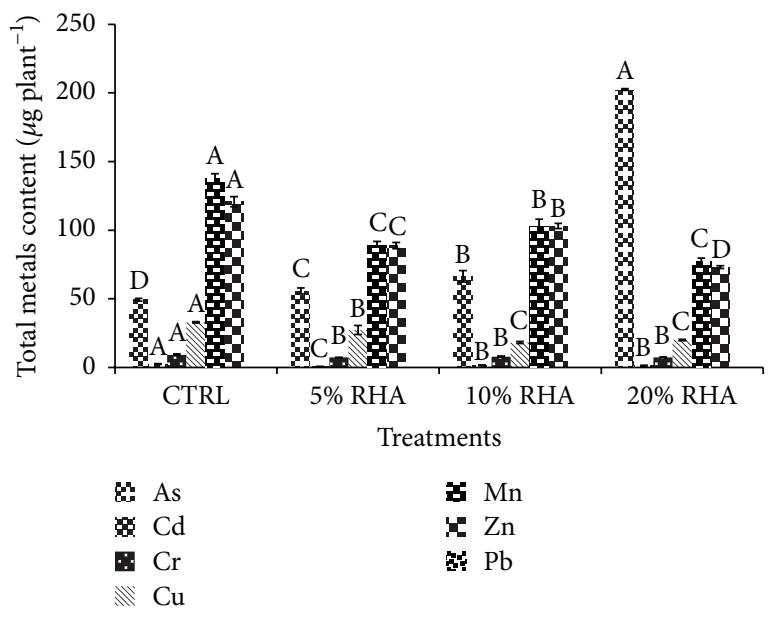

(a)
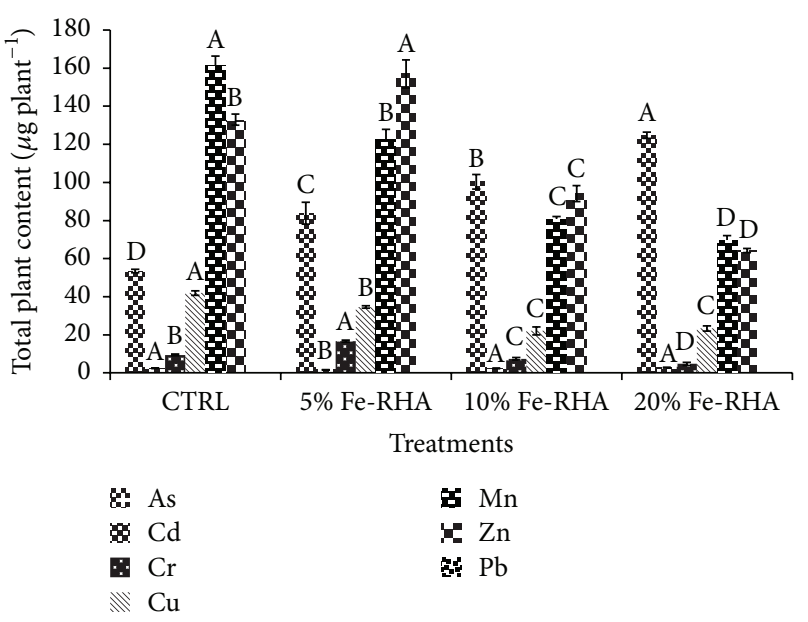

(b)

Figure 8: Total As, Cd, $\mathrm{Cr}, \mathrm{Cu}, \mathrm{Mn}, \mathrm{Zn}$, and $\mathrm{Pb}$ uptake $\left(\mu\right.$ p plant $^{-1}$ ) by vetiver grass grown in gold mine amended with Fe-RHA and RHA (mean $n=3, \pm \mathrm{SD}$ ). Different letters correspond to significant differences between rates of the same ash $(P<0.05)$. Pb was not detected.

uptake compared with the control. In contrast, the $\mathrm{Cr}$ and Zn uptakes by plants at 5\% Fe-RHA treated samples were higher compared with control (Figure $8(\mathrm{~b}))$. However, the total uptake of $\mathrm{Cr}$ and $\mathrm{Zn}$ by the vetiver grass decreased in $10 \%$ and $20 \%$ Fe-RHA treated samples. The application of type, rate, and the interaction term (type $*$ rate) of RHA had significant $(P<0.05)$ effect on the total plant uptake of all elements by the vetiver grass.

Reduction in root, shoot, and total dry biomass of vetiver grass grown in samples treated with RHA and Fe-RHA might be due to the increase in As uptake and other metals since the elements are toxic and could inhibit plant growth when present at high concentrations. Arsenic has direct toxic effect on the biochemical and physiological processes in the plant. When it is translocated to the shoot, As resulted in a decrease of plant growth and biomass accumulation by severely inhibiting plant growth and slowing or arresting expansion $[34,35]$. Eissa et al. [36] studied the phytoextraction of $\mathrm{Ni}$, $\mathrm{Pb}$, and $\mathrm{Cd}$ from contaminated soils using different field crops and EDTA treatment and they found that the root and shoot dry weights decreased by more than $25 \%$ due to the increase in metal plant uptake as a result of EDTA treatment.

Higher heavy metal uptake by the application of RHA on the gold mine tailings might be due to the presence of dissolved organic carbon (DOC). Previous studies found the positive correlations between mobility and availability of As and $\mathrm{Cu}$ with DOC [37]. The DOC affects the mobility of metals and metalloids through either the formation of soluble organic complexes or competition between the DOC and the metals for binding sites on the soil surface [38].

3.4. The Biological Accumulation Coefficient (BAC), Biological Transfer Coefficient (BTC), and Bioconcentration Factor (BCF) of the Vetiver Grass Grown in Mine Tailings Amended with RHA and $\mathrm{Fe}-\mathrm{RHA}$. The BACs values of $\mathrm{As}, \mathrm{Cd}, \mathrm{Cr}, \mathrm{Cu}, \mathrm{Mn}$, and $\mathrm{Zn}$ for vetiver grass grown in RHA and Fe-RHA amended tailings are shown in Table 5. The RHA treated samples at all rates showed a higher BAC for As compared with the control. The highest BAC for As (0.025) was recorded at 20\% RHA amended sample. The application of RHA at all rates did not significantly affect BACs value for $\mathrm{Cd}, \mathrm{Cr}$, and $\mathrm{Mn}$ compared with the control but the BAC value for the $\mathrm{Zn}$ was reduced with the application RHA at all rates. The lowest BAC value for $\mathrm{Zn}(0.393)$ was recorded at $20 \%$ of the RHA amended sample. In Fe-RHA amended samples, only the 5\% treatment had lower BAC value for As compared with the control while there is no significant effect at all rates on BACs value for $\mathrm{Cd}$ and $\mathrm{Cu}$. On the other hand, the BAC values of $\mathrm{Mn}$ and $\mathrm{Zn}$ were reduced by the application of Fe-RHA at all rates compared with the control. The lowest BAC values for $\mathrm{Mn}$ (0.118) and $\mathrm{Zn}(0.356)$ were both recorded in $20 \%$ Fe-RHA samples (Table 5).

The RHA mended samples showed higher BTC values for $\mathrm{Cu}$ at all rates compared with the control. The highest BTC for $\mathrm{Cu}$ (2.389) was recorded at 5\% RHA treated sample, respectively. In contrast, the $\mathrm{BTC}$ values for $\mathrm{As}, \mathrm{Mn}$, and $\mathrm{Zn}$ were lower than the control except for 10\% RHA for As and $5 \%$ RHA for Mn amended samples. The lowest BTC values for As (0.104), Mn (1.283), and Zn (0.334) were observed at 20\%, $10 \%$, and $10 \%$ RHA, respectively. The BTC values for $\mathrm{Cr}$ were lower than the control except for 5\% RHA amended samples. It is also observed that there was no significant effect of RHA application on the BTC values of vetiver grass for $\mathrm{Cd}$.

Meanwhile, in Fe-RHA amended samples, the BTC values for $\mathrm{As}, \mathrm{Mn}$, and $\mathrm{Zn}$ were lower than the control except at $5 \% \mathrm{Fe}-\mathrm{RHA}$ for Mn. The lowest BTC values for As (0.075), $\mathrm{Mn}$ (1.857), and $\mathrm{Zn}$ (0.363) were all observed in $20 \%$ Fe-RHA amended samples. In addition, there is no effect of Fe-RHA application at all rates on $\mathrm{BTC}$ value of $\mathrm{Cd}, \mathrm{Cr}$, and $\mathrm{Cu}$ except at $5 \% \mathrm{Fe}$-RHA for $\mathrm{Cd}$ and $\mathrm{Cr}$ and $10 \% \mathrm{Fe}-\mathrm{RHA}$ for $\mathrm{Cu}$.

Table 5 also shows the BCF value for the elements in vetiver grass grown in tailings amended with RHA and FeRHA. The BCF values for As and $\mathrm{Zn}$ in RHA and Fe-RHA amended samples at all rates were higher than the control. 
TABLE 5: Biological accumulation coefficient (BAC), biological transfer coefficient (BTC), and bioconcentration factor (BCF) of heavy metals by vetiver grass grown in the gold mine tailings amended with Fe-RHA and RHA (mean $n=3$ ). Different letters correspond to significant differences between rates of the same ash $(P<0.05)$ in the same column.

\begin{tabular}{|c|c|c|c|c|c|c|c|c|}
\hline & Type & Rate (\%) & As & $\mathrm{Cd}$ & $\mathrm{Cr}$ & $\mathrm{Cu}$ & $\mathrm{Mn}$ & $\mathrm{Zn}$ \\
\hline \multirow{8}{*}{ BAC } & Control & 0 & $0.009^{c}$ & $0.011^{\mathrm{a}}$ & $0.315^{\mathrm{a}}$ & $0.493^{\mathrm{b}}$ & $0.174^{\mathrm{a}}$ & $0.858^{\mathrm{a}}$ \\
\hline & RHA & 5 & $0.010^{c}$ & $0.015^{\mathrm{a}}$ & $0.375^{\mathrm{a}}$ & $0.640^{\mathrm{a}}$ & $0.148^{\mathrm{a}}$ & $0.533^{\mathrm{b}}$ \\
\hline & RHA & 10 & $0.020^{\mathrm{b}}$ & $0.017^{\mathrm{a}}$ & $0.343^{\mathrm{a}}$ & $0.422^{\mathrm{b}}$ & $0.129^{\mathrm{a}}$ & $0.436^{\mathrm{c}}$ \\
\hline & RHA & 20 & $0.025^{\mathrm{a}}$ & $0.016^{\mathrm{a}}$ & $0.369^{\mathrm{a}}$ & $0.542^{\mathrm{ab}}$ & $0.137^{\mathrm{a}}$ & $0.393^{\mathrm{c}}$ \\
\hline & Control & 0 & $0.009^{\mathrm{a}}$ & $0.009^{\mathrm{a}}$ & $0.257^{\mathrm{b}}$ & $0.619^{\mathrm{a}}$ & $0.200^{\mathrm{a}}$ & $0.816^{\mathrm{a}}$ \\
\hline & Fe-RHA & 5 & $0.006^{\mathrm{b}}$ & $0.011^{\mathrm{a}}$ & $0.643^{\mathrm{a}}$ & $0.603^{\mathrm{a}}$ & $0.166^{\mathrm{b}}$ & $0.567^{\mathrm{b}}$ \\
\hline & Fe-RHA & 10 & $0.011^{\mathrm{a}}$ & $0.015^{\mathrm{a}}$ & $0.314^{\mathrm{b}}$ & $0.564^{\mathrm{a}}$ & $0.134^{c}$ & $0.739^{c}$ \\
\hline & $\mathrm{Fe}-\mathrm{RHA}$ & 20 & $0.011^{\mathrm{a}}$ & $0.011^{\mathrm{a}}$ & $0.256^{\mathrm{b}}$ & $0.610^{\mathrm{a}}$ & $0.118^{\mathrm{c}}$ & $0.365^{\mathrm{d}}$ \\
\hline \multirow{8}{*}{ BTC } & Control & 0 & $0.321^{\mathrm{b}}$ & $0.211^{\mathrm{b}}$ & $3.089^{\mathrm{b}}$ & $1.554^{\mathrm{b}}$ & $2.802^{\mathrm{a}}$ & $1.119^{\mathrm{a}}$ \\
\hline & RHA & 5 & $0.198^{c}$ & $2.000^{\mathrm{a}}$ & $7.821^{\mathrm{a}}$ & $2.389^{\mathrm{a}}$ & $3.355^{\mathrm{a}}$ & $0.449^{\mathrm{b}}$ \\
\hline & RHA & 10 & $0.411^{\mathrm{a}}$ & $0.532^{\mathrm{b}}$ & $2.054^{\mathrm{b}}$ & $2.215^{\mathrm{a}}$ & $1.283^{\mathrm{c}}$ & $0.334^{\mathrm{b}}$ \\
\hline & RHA & 20 & $0.104^{\mathrm{d}}$ & $0.351^{\mathrm{b}}$ & $2.394^{\mathrm{b}}$ & $2.031^{\mathrm{a}}$ & $1.925^{\mathrm{b}}$ & $0.356^{\mathrm{b}}$ \\
\hline & Control & 0 & $0.329^{\mathrm{a}}$ & $0.201^{\mathrm{ab}}$ & $2.153^{\mathrm{b}}$ & $1.631^{\mathrm{b}}$ & $2.782^{\mathrm{a}}$ & $0.981^{\mathrm{a}}$ \\
\hline & Fe-RHA & 5 & $0.104^{\mathrm{b}}$ & $0.357^{\mathrm{a}}$ & $5.350^{\mathrm{a}}$ & $2.031^{\mathrm{ab}}$ & $2.957^{\mathrm{a}}$ & $0.314^{\mathrm{d}}$ \\
\hline & Fe-RHA & 10 & $0.127^{\mathrm{b}}$ & $0.273^{\mathrm{ab}}$ & $2.183^{\mathrm{b}}$ & $2.497^{\mathrm{a}}$ & $2.193^{\mathrm{b}}$ & $0.715^{\mathrm{b}}$ \\
\hline & Fe-RHA & 20 & $0.075^{\mathrm{c}}$ & $0.112^{\mathrm{b}}$ & $2.927^{\mathrm{b}}$ & $1.867^{\mathrm{b}}$ & $1.857^{\mathrm{c}}$ & $0.363^{\mathrm{c}}$ \\
\hline \multirow{8}{*}{ BCF } & Control & 0 & $0.027^{\mathrm{c}}$ & $0.051^{\mathrm{a}}$ & $0.102^{\mathrm{b}}$ & $0.318^{\mathrm{a}}$ & $0.062^{c}$ & $0.770^{c}$ \\
\hline & RHA & 5 & $0.051^{\mathrm{b}}$ & $0.008^{c}$ & $0.049^{c}$ & $0.267^{\mathrm{a}}$ & $0.044^{\mathrm{d}}$ & $1.192^{\mathrm{ab}}$ \\
\hline & RHA & 10 & $0.050^{\mathrm{b}}$ & $0.032^{\mathrm{b}}$ & $0.167^{\mathrm{a}}$ & $0.191^{\mathrm{b}}$ & $0.100^{\mathrm{a}}$ & $1.307^{\mathrm{a}}$ \\
\hline & RHA & 20 & $0.243^{\mathrm{a}}$ & $0.044^{\mathrm{ab}}$ & $0.155^{\mathrm{a}}$ & $0.267^{\mathrm{a}}$ & $0.071^{\mathrm{b}}$ & $1.108^{\mathrm{b}}$ \\
\hline & Control & 0 & $0.027^{\mathrm{d}}$ & $0.045^{\mathrm{b}}$ & $0.119^{\mathrm{ab}}$ & $0.380^{\mathrm{a}}$ & $0.072^{\mathrm{a}}$ & $0.832^{c}$ \\
\hline & Fe-RHA & 5 & $0.062^{c}$ & $0.032^{c}$ & $0.120^{\mathrm{ab}}$ & $0.296^{\mathrm{ab}}$ & $0.056^{\mathrm{ab}}$ & $1.806^{\mathrm{a}}$ \\
\hline & Fe-RHA & 10 & $0.084^{\mathrm{b}}$ & $0.056^{\mathrm{b}}$ & $0.145^{\mathrm{a}}$ & $0.229^{\mathrm{b}}$ & $0.061^{\mathrm{b}}$ & $1.035^{\mathrm{b}}$ \\
\hline & Fe-RHA & 20 & $0.145^{\mathrm{a}}$ & $0.101^{\mathrm{a}}$ & $0.088^{\mathrm{b}}$ & $0.327^{\mathrm{a}}$ & $0.064^{\mathrm{ab}}$ & $1.005^{\mathrm{b}}$ \\
\hline
\end{tabular}

The highest BCF values of As (0.243) and $\mathrm{Zn}$ (1.806) were recorded by $20 \%$ RHA and $5 \%$ Fe-RHA samples, respectively. The application of RHA at all rates except at $20 \%$ reduced BCF value for Cd compared with the control and the lowest BCF value for $\mathrm{Cd}(0.008)$ was recorded at $5 \% \mathrm{RHA}$. The application of $10 \%$ and $20 \%$ RHA increased the BCF values for $\mathrm{Cr}$, while at 5\% RHA the values decreased compared to the control. However, for $\mathrm{Cu}$ only the $10 \% \mathrm{RHA}$ amended sample had lower BCF value compared with the control. Samples treated with Fe-RHA at lower rates had lower BCF values for Cd than the control but, at $20 \% \mathrm{Fe}-\mathrm{RHA}$, the BCF value was higher than the control. The application of Fe-RHA did not significantly affect the BCF values of $\mathrm{Cr}, \mathrm{Cu}$, and $\mathrm{Mn}$ at all rates, except at $10 \% \mathrm{Fe}-\mathrm{RHA}$ for $\mathrm{Cu}$ and $\mathrm{Mn}$.

A plant is a hyperaccumulator when the heavy metal concentration in its stem and leaf is 10-500 times higher than in plants grown in nonpolluted area and enrichment coefficient is greater than 1 [39]. In general, it can be concluded that the success of a heavy metal-phytoextraction process depends on the ability of the plant to move the metals quickly from the root to the aerial parts of the plant [40]. Though the concentrations of metals were high in the shoot system of the vetiver grass, the BAC values for all heavy metals were less than 1 (Table 5), and this may be attributed to the very high concentration of contamination in gold mine tailings because the $\mathrm{BAC}$ value is the ratio of concentration from the tailings to the shoots.

The mobility of heavy metals from the roots to the shoots is reflected by the BTC values. The results show that the BTC values for $\mathrm{Cd}, \mathrm{Cr}, \mathrm{Cu}, \mathrm{Mn}$, and $\mathrm{Zn}$ were greater than 1 , while the BTC values for As were less than 1 . The BTC values suggest higher concentrations of $\mathrm{Cd}, \mathrm{Cr}, \mathrm{Cu}, \mathrm{Mn}$, and $\mathrm{Zn}$ in the shoots than the roots system of the vetiver grass, while for As, the opposite was true. Also, BTC and BAC results indicated the ability of vetiver grass to absorb $\mathrm{Cd}, \mathrm{Cr}, \mathrm{Cu}$, $\mathrm{Mn}$, and $\mathrm{Zn}$ and they were rapidly transferred to shoot. In contrast, the results of As clearly showed the affinity of roots to accumulate a good amount of metals from the tailings but low transfer to the aerial parts. The BCF indicates root metal concentration divided by the tailings concentration. The value was used to explain the uptake of vetiver in roots. The BCF values for all metals except $\mathrm{Zn}$ were less than 1 (Table 5) which considered normal because the values demonstrated the ability of vetiver to accumulate a good amount of metals in the root. This might be due to variation in heavy metal concentration and plant species. The BCF values reflected the negative effect of adding RHA to uptake of heavy metals by the vetiver. The overall results indicate that the vetiver 
grass can grow in the gold mine tailing containing high concentrations of $\mathrm{As}, \mathrm{Cd}, \mathrm{Cr}, \mathrm{Cu}, \mathrm{Mn}, \mathrm{Pb}$, and $\mathrm{Zn}$ and can accumulate the elements in its roots and shoots.

\section{Conclusions}

It can be concluded from this study that the vetiver grass was tolerant to high concentrations of $\mathrm{As}, \mathrm{Cd}, \mathrm{Cr}, \mathrm{Cu}, \mathrm{Mn}$, and $\mathrm{Zn}$ in the tailings. Application of RHA and Fe-RHA reduced the phytoavailability of $\mathrm{Cd}, \mathrm{Cr}, \mathrm{Cu}, \mathrm{Mn}$, and $\mathrm{Zn}$. This may be important during the early part of a phytoremediation project whereby establishment of plant species on tailings containing very high concentrations of heavy metals is difficult. On the other hand, both amendments especially the RHA can also be used to increase the phytoavailability of As. Therefore, the RHA and Fe-RHA can be used in a phytoremediation project to either reduce the phytoavailability of cationic elements like $\mathrm{Cd}, \mathrm{Cr}, \mathrm{Cu}, \mathrm{Mn}$, and $\mathrm{Zn}$ or increase the phytoavailability of anionic elements like As. We recommend that field experiments should be carried out to confirm the results obtained in this glass house study.

\section{Competing Interests}

The authors declare that they have no competing interests.

\section{Acknowledgments}

The authors acknowledge the financial support by the University Putra Malaysia through Research Grant GPIBT/2013/9418500. Mr. F. S. Tariq received a scholarship for his Ph.D. study under the Human Capacity Development Program of Kurdistan Regional Government of Iraq. The authors also thank the anonymous reviewers for their comments and suggestions.

\section{References}

[1] S. Taberima, B. Mulyanto, R. J. Gilkes, and Y. Husin, "Fertility status of soils developed on an inactive mine tailings deposition area in Papua," in Proceedings of the 19th World Congress of Soil Science, Soil Solutions for a Changing World, pp. 21-26, Brisbane, Australia, August 2010.

[2] M. C. Navarro, C. Pérez-Sirvent, M. J. Martínez-Sánchez, J. Vidal, P. J. Tovar, and J. Bech, "Abandoned mine sites as a source of contamination by heavy metals: a case study in a semi-arid zone," Journal of Geochemical Exploration, vol. 96, no. 2-3, pp. 183-193, 2008.

[3] W. H. O. Ernst, "Bioavailability of heavy metals and decontamination of soils by plants," Applied Geochemistry, vol. 11, no. 1-2, pp. 163-167, 1996.

[4] A. Akcil, C. Erust, S. Ozdemiroglu, V. Fonti, and F. Beolchini, "A review of approaches and techniques used in aquatic contaminated sediments: metal removal and stabilization by chemical and biotechnological processes," Journal of Cleaner Production, vol. 86, pp. 24-26, 2015

[5] S. Khan, M. Waqas, F. Ding, I. Shamshad, H. P. H. Arp, and G. Li, "The influence of various biochars on the bioaccessibility and bioaccumulation of PAHs and potentially toxic elements to turnips (Brassica rapa L.)," Journal of Hazardous Materials, vol. 300, pp. 243-253, 2015.

[6] M. Ahmad, S. S. Lee, J. E. Yang, H.-M. Ro, Y. Han Lee, and Y. Sik Ok, "Effects of soil dilution and amendments (mussel shell, cow bone, and biochar) on $\mathrm{Pb}$ availability and phytotoxicity in military shooting range soil," Ecotoxicology and Environmental Safety, vol. 79, pp. 225-231, 2012.

[7] A. S. Chamon, M. H. Gerzabek, M. N. Mondol, S. M. Ullah, M. Rahman, and W. E. H. Blum, "Influence of soil amendments on heavy metal accumulation in crops on polluted soils of Bangladesh," Communications in Soil Science and Plant Analysis, vol. 36, no. 7-8, pp. 907-924, 2005.

[8] R. P. Narwal and B. R. Singh, "Effect of organic materials on partitioning, extractability and plant uptake of metals in an alum shale soil," Water, Air, and Soil Pollution, vol. 103, no. 14, pp. 405-421, 1998.

[9] R. P. Singh and M. Agrawal, "Variations in heavy metal accumulation, growth and yield of rice plants grown at different sewage sludge amendment rates," Ecotoxicology and Environmental Safety, vol. 73, no. 4, pp. 632-641, 2010.

[10] Ministry of Science, Technology, and the Environment of Malaysia, National Policy on the Environment, 2002.

[11] A. B. Hashim, H. Aminuddin, and K. B. Siva, "Nutrient content in rice husk ash of some Malaysian rice varieties," Pertanika Journal of Tropical Agricultural Science, vol. 19, no. 1, pp. 77-80, 1996.

[12] Q. Feng, Q. Lin, F. Gong, S. Sugita, and M. Shoya, "Adsorption of lead and mercury by rice husk ash," Journal of Colloid and Interface Science, vol. 278, no. 1, pp. 1-8, 2004.

[13] C. R. T. Tarley and M. A. Z. Arruda, "Biosorption of heavy metals using rice milling by-products. Characterisation and application for removal of metals from aqueous effluents," Chemosphere, vol. 54, no. 7, pp. 987-995, 2004.

[14] V. C. Srivastava, I. D. Mall, and I. M. Mishra, "Removal of cadmium(II) and zinc(II) metal ions from binary aqueous solution by rice husk ash," Colloids and Surfaces A: Physicochemical and Engineering Aspects, vol. 312, no. 2-3, pp. 172-184, 2008.

[15] V. C. Srivastava, I. D. Mall, and I. M. Mishra, "Characterization of mesoporous rice husk ash (RHA) and adsorption kinetics of metal ions from aqueous solution onto RHA," Journal of Hazardous Materials, vol. 134, no. 1-3, pp. 257-267, 2006.

[16] V. S. Mane, I. D. Mall, and V. C. Srivastava, "Kinetic and equilibrium isotherm studies for the adsorptive removal of Brilliant Green dye from aqueous solution by rice husk ash," Journal of Environmental Management, vol. 84, no. 4, pp. 390400, 2007.

[17] J. C. Saha, K. Dikshit, and M. Bandyopadhyay, "Comparative studies for selection of technologies for arsenic removal from drinking water," in Proceedings of the BUET-UNU International Workshop on Technologies for Arsenic Removal from Drinking Water, pp. 76-84, Dhaka, Bangladesh, 2001.

[18] W. Nakbanpote, P. Thiravetyan, and C. Kalambaheti, "Preconcentration of gold by rice husk ash," Minerals Engineering, vol. 13, no. 4, pp. 391-400, 2000.

[19] C.-Y. Yin, H. B. Mahmud, and M. G. Shaaban, "Stabilization/solidification of lead-contaminated soil using cement and rice husk ash," Journal of Hazardous Materials, vol. 137, no. 3, pp. 1758-1764, 2006.

[20] P. R. Day, "Particle fractionation and particle-size analysis," in Methods of Soil Analysis. Part 2. Chemical and Microbiological Properties, C. A. Black, D. D. Evans, J. L. White, L. E. Ensminger, 
and F. E. Clak, Eds., pp. 1367-1378, American Society of Agronomy, Madison, Wis, USA, 1965.

[21] H. D. Chapman, "Cation exchange capacity," in Methods of Soil Analysis. Part 2. Chemical and Microbiological Properties, G. A. Black, D. D. Evans, J. L. White, L. E. Ensminger, and F. E. Clark, Eds., pp. 891-901, American Society of Agronomy, Madison, Wis, USA, 1965.

[22] V. Cappuyns and R. Swennen, "Release of vanadium from oxidized sediments: insights from different extraction and leaching procedures," Environmental Science and Pollution Research, vol. 21, no. 3, pp. 2272-2282, 2014.

[23] W. S. Shu, Z. H. Ye, C. Y. Lan, Z. Q. Zhang, and M. H. Wong, "Acidification of lead/zinc mine tailings and its effect on heavy metal mobility," Environment International, vol. 26, no. 5-6, pp. 389-394, 2001

[24] L. E. Allison and C. D. Moodie, "Carbonate," in Methods of Soil Analysis. Part 2. Chemical and Microbiological Properties, G. A. Black, D. D. Evans, J. L. White, L. E. Ensminger, and F. E. Clak, Eds., pp. 1379-1396, American Society of Agronomy, Madison, Wis, USA, 1965.

[25] D. E. Güven and G. Akinci, "Comparison of acid digestion techniques to determine heavy metals in sediment and soil samples," Gazi University Journal of Science, vol. 24, no. 1, pp. 29-34, 2011.

[26] Ü. Uras, M. Carrier, A. G. Hardie, and J. H. Knoetze, "Physicochemical characterization of biochars from vacuum pyrolysis of South African agricultural wastes for application as soil amendments," Journal of Analytical and Applied Pyrolysis, vol. 98, pp. 207-213, 2012.

[27] M. Ahmedna, W. E. Marshall, and R. M. Rao, "Production of granular activated carbons from select agricultural by-products and evaluation of their physical, chemical and adsorption properties," Bioresource Technology, vol. 71, no. 2, pp. 113-123, 2000.

[28] W. Song and M. Guo, "Quality variations of poultry litter biochar generated at different pyrolysis temperatures," Journal of Analytical and Applied Pyrolysis, vol. 94, pp. 138-145, 2012.

[29] A. W. Samsuri, F. Sadegh-Zadeh, and B. J. Seh-Bardan, "Adsorption of $\mathrm{As}(\mathrm{III})$ and $\mathrm{As}(\mathrm{V})$ by Fe coated biochars and biochars produced from empty fruit bunch and rice husk," Journal of Environmental Chemical Engineering, vol. 1, no. 4, pp. 981-988, 2013.

[30] Z. Yanqun, L. Yuan, C. Jianjun, C. Haiyan, Q. Li, and C. Schvartz, "Hyperaccumulation of $\mathrm{Pb}, \mathrm{Zn}$ and $\mathrm{Cd}$ in herbaceous grown on lead-zinc mining area in Yunnan, China," Environment International, vol. 31, no. 5, pp. 755-762, 2005.

[31] J. Yoon, X. Cao, Q. Zhou, and L. Q. Ma, "Accumulation of Pb, $\mathrm{Cu}$, and $\mathrm{Zn}$ in native plants growing on a contaminated Florida site," Science of the Total Environment, vol. 368, no. 2-3, pp. 456464, 2006.

[32] S. Karmakar, B. N. Mittra, and B. C. Ghosh, "Influence of industrial solid wastes on soil-plant interactions in rice under acid lateritic soil," in Proceedings of the World of Coal Ash Conference, pp. 4-7, Lexington, Ky, USA, May 2009.

[33] A. Masulili, W. H. Utomo, and M. S. Syechfani, "Rice husk biochar for rice based cropping system in acid soil 1. the characteristics of rice husk biochar and its influence on the properties of acid sulfate soils and rice growth in West Kalimantan, Indonesia," Journal of Agricultural Science, vol. 2, no. 1, pp. 39-47, 2010.
[34] N. Garg and P. Singla, "Arsenic toxicity in crop plants: physiological effects and tolerance mechanisms," Environmental Chemistry Letters, vol. 9, no. 3, pp. 303-321, 2011.

[35] A. C. Barrachina, F. B. Carbonell, and J. M. Beneyto, "Arsenic uptake, distribution, and accumulation in tomato plants: effect of arsenite on plant growth and yield," Journal of Plant Nutrition, vol. 18, no. 6, pp. 1237-1250, 1995.

[36] M. A. Eissa, M. F. Ghoneim, G. A. El-Gharably, and M. A. El-Razek, "Phytoextraction of nickel, lead and cadmium from metals contaminated soils using different field crops and EDTA," World Applied Sciences Journal, vol. 32, no. 6, pp. 10451052, 2014.

[37] M. P. Bernal, R. Clemente, and D. J. Walker, "Interactions of heavy metals with soil organic matter in relation to phytoremediation," in Phytoremediation: The Green Salvation of the World, J. P. Navarro-Aviño, Ed., pp. 109-129, Research Signpost, Kerala, India, 2009.

[38] R. Clemente, N. M. Dickinson, and N. W. Lepp, "Mobility of metals and metalloids in a multi-element contaminated soil 20 years after cessation of the pollution source activity," Environmental Pollution, vol. 155, no. 2, pp. 254-261, 2008.

[39] Z. G. Shen and Y. L. Liu, "Progress in the study on the plants that hyperaccumulate heavy metal," Plant Physiology Communications, , vol. 34, pp. 133-139, 1998.

[40] M. J. Khan, M. T. Jan, N. U. Farhatullah et al., "The effect of using waste water for tomato," Pakistan Journal of Botany, vol. 43, no. 2, pp. 1033-1044, 2011. 

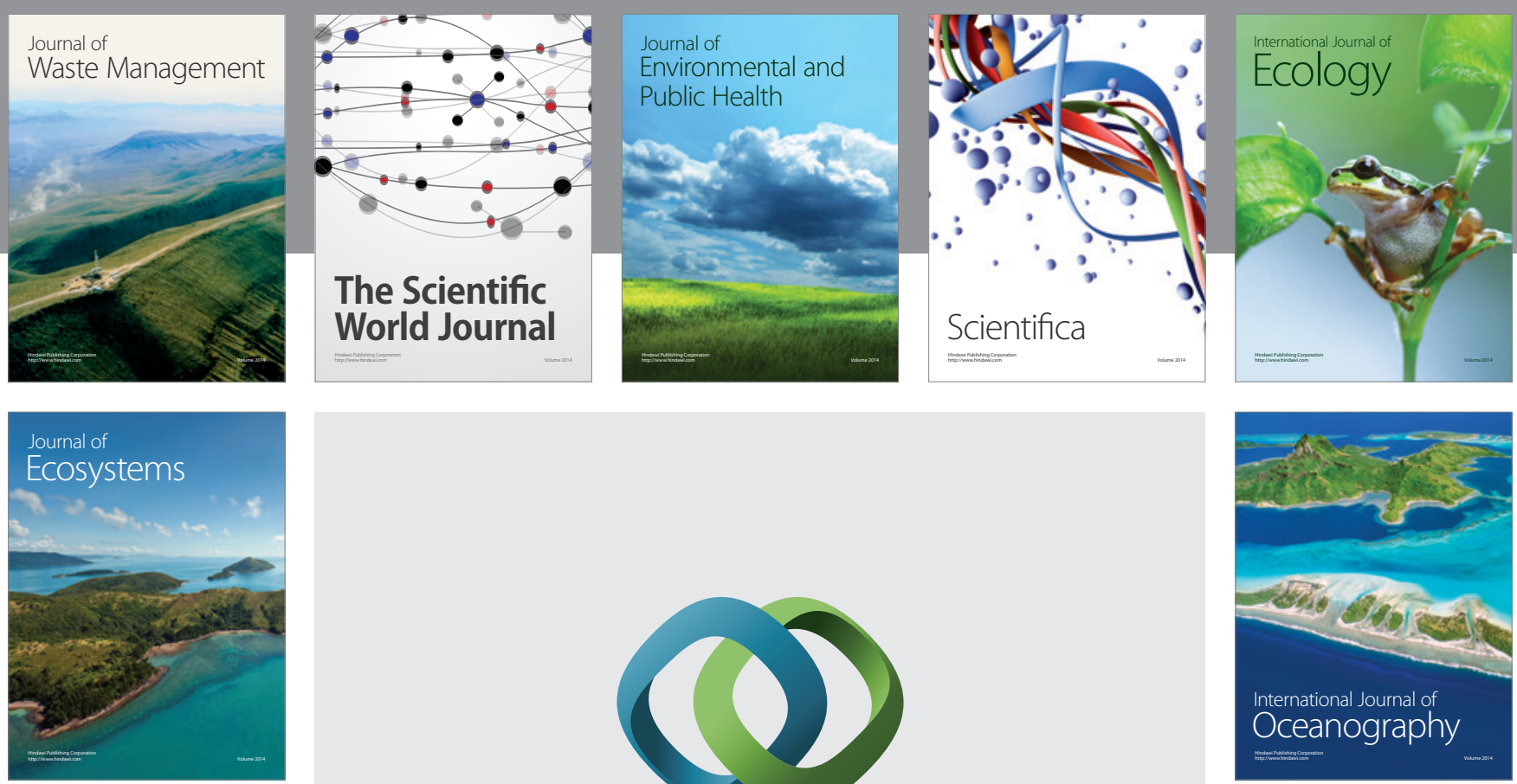

The Scientific World Journal
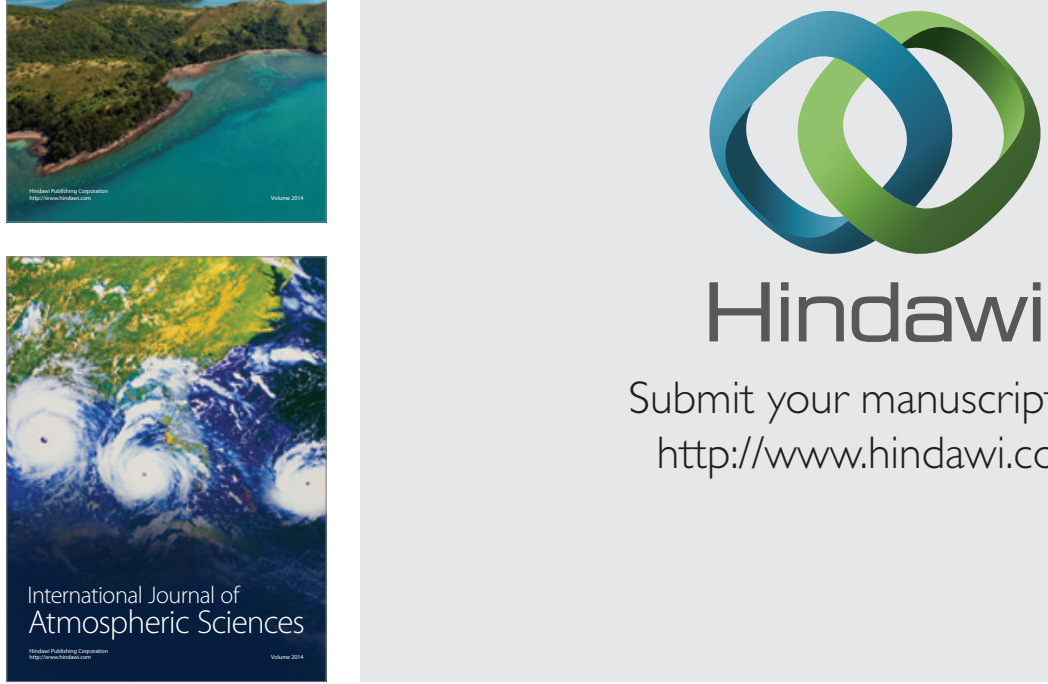

\section{Hindawi}

Submit your manuscripts at

http://www.hindawi.com
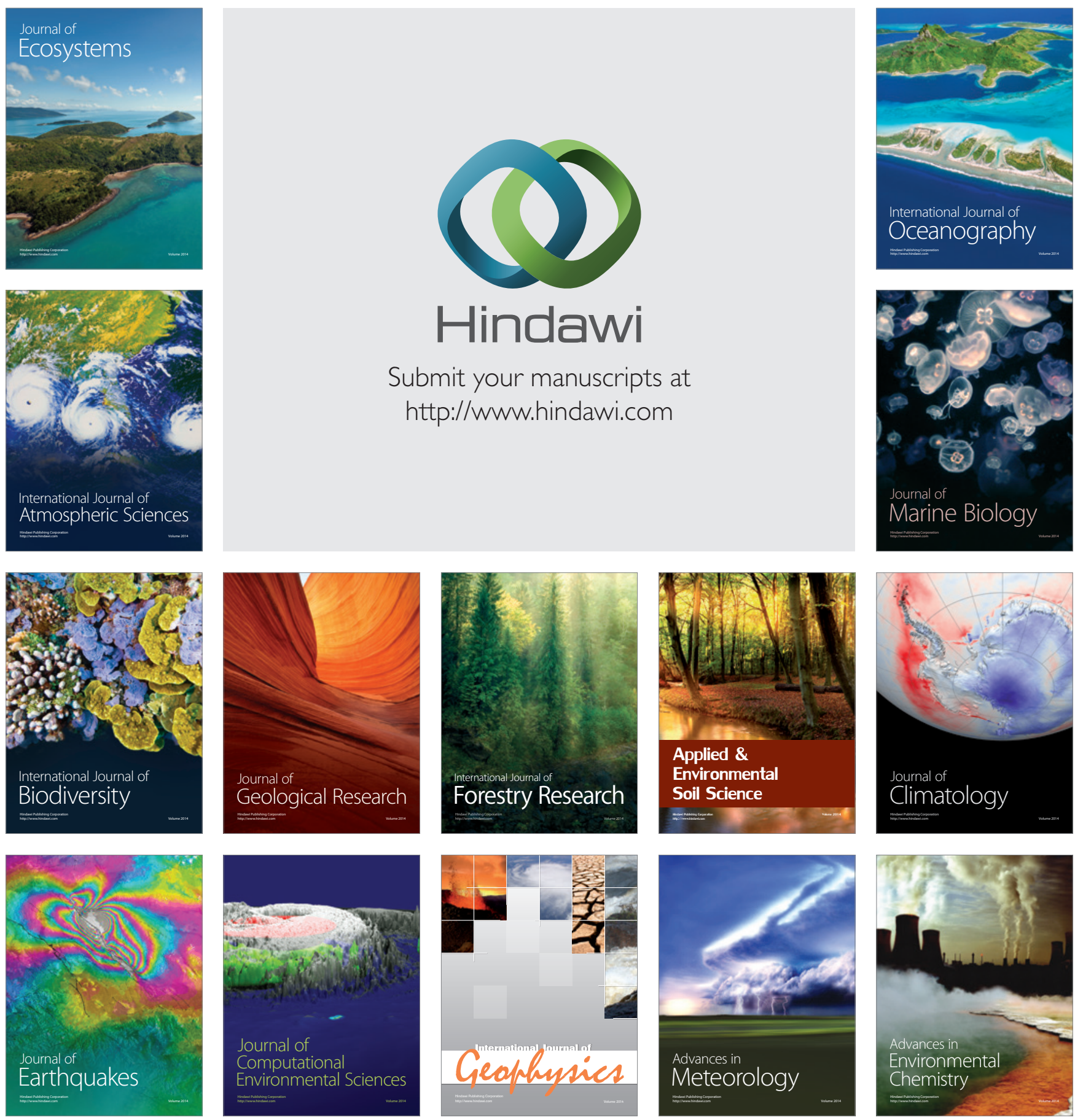